\title{
NEAR-SOURCE STRONG GROUND MOTIONS OBSERVED IN THE 22 FEBRUARY 2011 CHRISTCHURCH EARTHQUAKE
}

\author{
Brendon A. Bradley ${ }^{1}$, Misko Cubrinovski ${ }^{1}$
}

\begin{abstract}
SUMMARY
This manuscript provides a critical examination of the ground motions recorded in the near-source region resulting from the 22 February 2011 Christchurch earthquake. Particular attention is given to reconciling the observed spatial distribution of ground motions in terms of physical phenomena related to source, path and site effects. The large number of near-source observed strong ground motions show clear evidence of: forward-directivity, basin generated surface waves, liquefaction and other significant nonlinear site response. The pseudo-acceleration response spectra (SA) amplitudes and significant duration of strong motions agree well with empirical prediction models, except at long vibration periods where the influence of basin-generated surface waves and nonlinear site response are significant and not adequately accounted for in empirical SA models. Pseudo-acceleration response spectra are also compared with those observed in the 4 September 2010 Darfield earthquake and routine design response spectra used in order to emphasise the amplitude of ground shaking and elucidate the importance of local geotechnical characteristics on surface ground motions. The characteristics of the observed vertical component accelerations are shown to be strongly dependent on source-to-site distance and are comparable with those from the 4 September 2010 Darfield earthquake, implying the large amplitudes observed are simply a result of many observations at close distances rather than a peculiar source effect.
\end{abstract}

\section{INTRODUCTION}

On 22 February 2011 at 12:51pm local time, a moment magnitude $M_{w} 6.3$ earthquake occurred beneath the city of Christchurch, New Zealand, causing an unparalleled level of damage in the country's history, and the largest number of causalities since the 1931 Hawkes Bay (Napier) earthquake. Compared to the preceding 4 September $2010 M_{w} 7.1$ Darfield earthquake, which occurred approximately $35 \mathrm{~km}$ to the west of Christchurch, the close proximity of the 22 February event lead to ground motions of significantly higher amplitude in the densely populated regions of Christchurch. As a result of these significantly larger ground motions, structures in general, and commercial structures in the central business district in particular, were subjected to severe seismic demands and, combined with the event timing structural collapses accounted for the majority of the 182 causalities [1].

The following section provides a brief overview of the tectonic and geologic setting of the Canterbury region in order to provide context for the observed ground motions which are discussed in subsequent sections on the basis of source, path and site effects, and comparisons with empirical prediction models, design guidelines, and those of the 4 September 2010 Darfield earthquake.

\section{TECTONIC AND GEOLOGIC SETTING}

New Zealand resides on the boundary of the Pacific and Australian plates (Figure 1) and its active tectonics are dominated by: (i) oblique subduction of the Pacific plate beneath the Australian plate along the Hikurangi trough in the North island; (ii) oblique subduction of the Australian plate beneath the Pacific plate along the Puysegur trench in the south west of the South island; and (iii) oblique, right lateral slip along numerous crustal faults in the axial tectonic belt, of which the 650-km long Alpine fault is inferred to accommodate approximately $70-75 \%$ of the approximately $40 \mathrm{~mm} / \mathrm{yr}$ plate motion $[2,3]$.

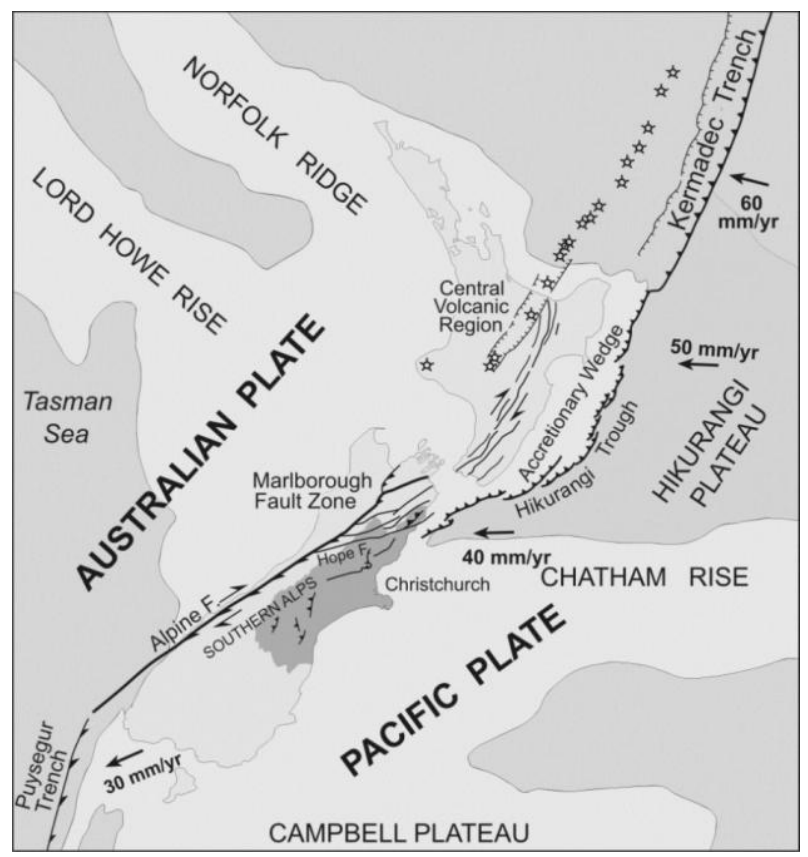

Figure 1: Tectonic setting of New Zealand.

\footnotetext{
${ }^{1}$ Department of Civil and Natural Resources Engineering, University of Canterbury, Christchurch (member)
} 
There are numerous identified faults in the Southern Alps and eastern foothills [4] and several significant earthquakes (i.e. $M_{w}>6$ ) have occurred in this region in the past 150 years, most notably the 4 September $2010 M_{w} 7.1$ Darfield earthquake [5]. The $M_{w} 6.3$ Christchurch earthquake occurred at $12: 51 \mathrm{pm}$ on Tuesday 22 February 2011 beneath Christchurch, New Zealand's second largest city, and represents the most significant earthquake in the unfolding seismic sequence in the Canterbury region since the Darfield earthquake. Herein, a moment magnitude of 6.3 is used with reference to this event, however it is noted that reported values range from $M_{w} 6.3$ for a geodetic finite fault model [6], 6.2 for regional moment tensor solutions (J. Ristau, pers. comm.), and 6.1 for the USGS teleseismic moment tensor solution. The $M_{w} 6.3$ event occurred on a previously unrecognised deeply-dipping blind fault, which trends north-east to south-west (the location relative to Christchurch is presented in the context of observed ground motions subsequently). Figure 2 illustrates the inferred slip distribution on the fault obtained by Beavan et al. [6]. It can be seen that slip on the fault occurred obliquely with both significant up-dip and along-strike components (average rake, $\lambda=146^{\circ}$ ). For the purpose of the subsequent engineering analysis of strong ground motion, the Beavan $e t$ al. finite fault model was 'trimmed' using the methodology of Somerville et al. [7], which resulted in the removal of $1 \mathrm{~km}$ from the Northeast and Southwest extents of Figure 2. The resulting 'trimmed' fault therefore has dimensions of $15 \mathrm{~km}$ along-strike and $8 \mathrm{~km}$ down-dip, giving a total area of $120 \mathrm{~km}^{2}$.

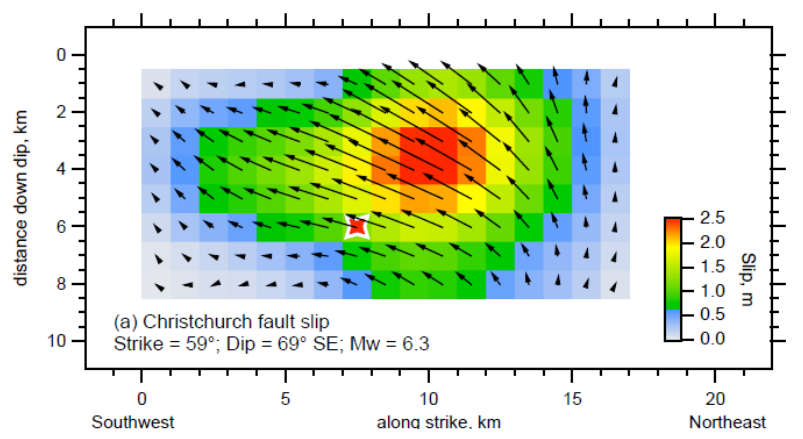

Figure 2: Distribution of fault slip inferred in the 22/02/2011 Christchurch earthquake [6]. Arrows indicate the slip vector and the inferred hypocenter is indicated by a star.
Christchurch is located on the Canterbury plains, a fan deposit resulting from the numerous rivers flowing eastward from the foothills of the Southern Alps [8]. In the vicinity of Christchurch, the Canterbury plains are comprised of a complex sequence of gravels interbedded with silt, clay, peat, and shelly sands. The fine sediments form aquicludes and aquitards between the gravel aquifers, and with the nearby coastline to the east, result in the majority of Christchurch having a water table less than $5 \mathrm{~m}$ depth, with the majority of the area including, and to the east of, the central business district having a water table less than $1 \mathrm{~m}$ from the surface [8]. The postglacial 'Christchurch formation' created by estuarine, lagoonal, dune, and coastal swamp deposits (containing gravel, sand, silt, clay, shell and peat) is the predominant surface geology layer in the Christchurch area which outcrops up to $11 \mathrm{~km}$ west of the coast and has a depth of approximately $40 \mathrm{~km}$ along the coast itself [8]. At the southeast edge of Christchurch lies the extinct Banks Peninsula volcanic complex.

\section{SUMMARY OF OBSERVED STRONG MOTIONS}

Volume 1 ground motion records were obtained from GeoNet (www.geonet.org.nz/) and processed on a record-by-record basis. Table 1 presents a summary of the ground motions in the wider Christchurch region that were recorded within a source-to-site distance of $R_{\text {rup }}=20 \mathrm{~km}$, including: station site class (SC) according to the current New Zealand loading standard, NZS1170.5:2004 [9], peak ground acceleration $(P G A)$, and peak ground velocity $(P G V)$ for geometric mean horizontal component; and peak vertical ground acceleration $\left(P G A_{V}\right)$. It can be seen that significant ground motions were recorded in this event with ground motions of up to $1.41 \mathrm{~g}$ in the horizontal component (at Heathcote Valley, HVSC), and 7 and 16 records having PGA's exceeding $0.4 \mathrm{~g}$ and $0.2 \mathrm{~g}$, respectively. To put such numbers in context it is noted that prior to the Darfield earthquake the maximum recorded PGA in New Zealand was $0.39 \mathrm{~g}$ [10]. Figure 3 illustrates the spatial distribution of fault-normal, fault-parallel, and vertical ground motions observed in Christchurch City. The subsequent sections elaborate on the salient features which can be observed in Figure 3 and Table 1.

Table 1: Summary of observed ground motions at strong motion stations in the 22 February 2011 Christchurch earthquake.

\begin{tabular}{|c|c|c|c|c|c|c|c|c|c|c|c|}
\hline Station Name & Code & $S C$ & $\begin{array}{l}R_{\text {rup }} \\
(\mathrm{km})\end{array}$ & $\begin{array}{c}P G A \\
(\mathrm{~g})\end{array}$ & $\begin{array}{c}P G A_{v} \\
P G A_{w}(\mathrm{~g})\end{array}$ & Station Name & Code & $S C$ & $\begin{array}{l}R_{\mathrm{ruy}} \\
(\mathrm{km})\end{array}$ & $\begin{array}{c}P G A \\
(\mathrm{~g})\end{array}$ & $\begin{array}{c}P G A_{v} \\
(\mathrm{~g})\end{array}$ \\
\hline Canterbury Aero Club & CACS & $D$ & 12.8 & 0.21 & 0.19 & $\begin{array}{c}\text { Lyttelton Port Naval } \\
\text { Point }\end{array}$ & LPOC & $C$ & 6.6 & 0.34 & 0.39 \\
\hline $\begin{array}{c}\text { Christchurch Botanic } \\
\text { Gardens }\end{array}$ & CBGS & $D$ & 4.7 & 0.50 & 0.35 & $\begin{array}{l}\text { North New Brighton } \\
\text { School }\end{array}$ & NNBS & $E$ & 3.8 & 0.67 & 0.80 \\
\hline $\begin{array}{c}\text { Christchurch Cathedral } \\
\text { College }\end{array}$ & $\mathrm{CCCC}$ & $D$ & 2.8 & 0.43 & 0.79 & Papanui High School & PPHS & $D$ & 8.6 & 0.21 & 0.21 \\
\hline Christchurch Hospital & $\mathrm{CHHC}$ & $D$ & 3.8 & 0.37 & 0.62 & $\begin{array}{l}\text { Pages Rd Pumping } \\
\text { Station }\end{array}$ & PRPC & $E$ & 2.5 & 0.63 & 1.88 \\
\hline Cashmere High School & CMHS & $D$ & 1.4 & 0.37 & 0.85 & Christchurch Resthaven & REHS & $D$ & 4.7 & 0.52 & 0.51 \\
\hline $\begin{array}{c}\text { Hulverstone Dr Pumping } \\
\text { Station }\end{array}$ & HPSC & $E$ & 3.9 & 0.22 & 1.03 & Riccarton High School & RHSC & $D$ & 6.5 & 0.28 & 0.19 \\
\hline Heathcote Valley School & HVSC & $C$ & 4.0 & 1.41 & 2.21 & Rolleston School & ROLC & $D$ & 19.6 & 0.18 & 0.08 \\
\hline Kaipoi North School & KPOC & $E$ & 17.4 & 0.20 & 0.06 & Shirley Library & SHLC & $D$ & 5.1 & 0.33 & 0.49 \\
\hline Lincoln School & LINC & $D$ & 13.6 & 0.12 & 0.09 & $\begin{array}{l}\text { Styx Mill Transfer } \\
\text { Station }\end{array}$ & SMTC & $D$ & 10.8 & 0.16 & 0.17 \\
\hline Lyttelton Port & LPCC & $B$ & 7.1 & 0.92 & 0.51 & Templeton School & TPLC & $D$ & 12.5 & 0.11 & 0.16 \\
\hline
\end{tabular}



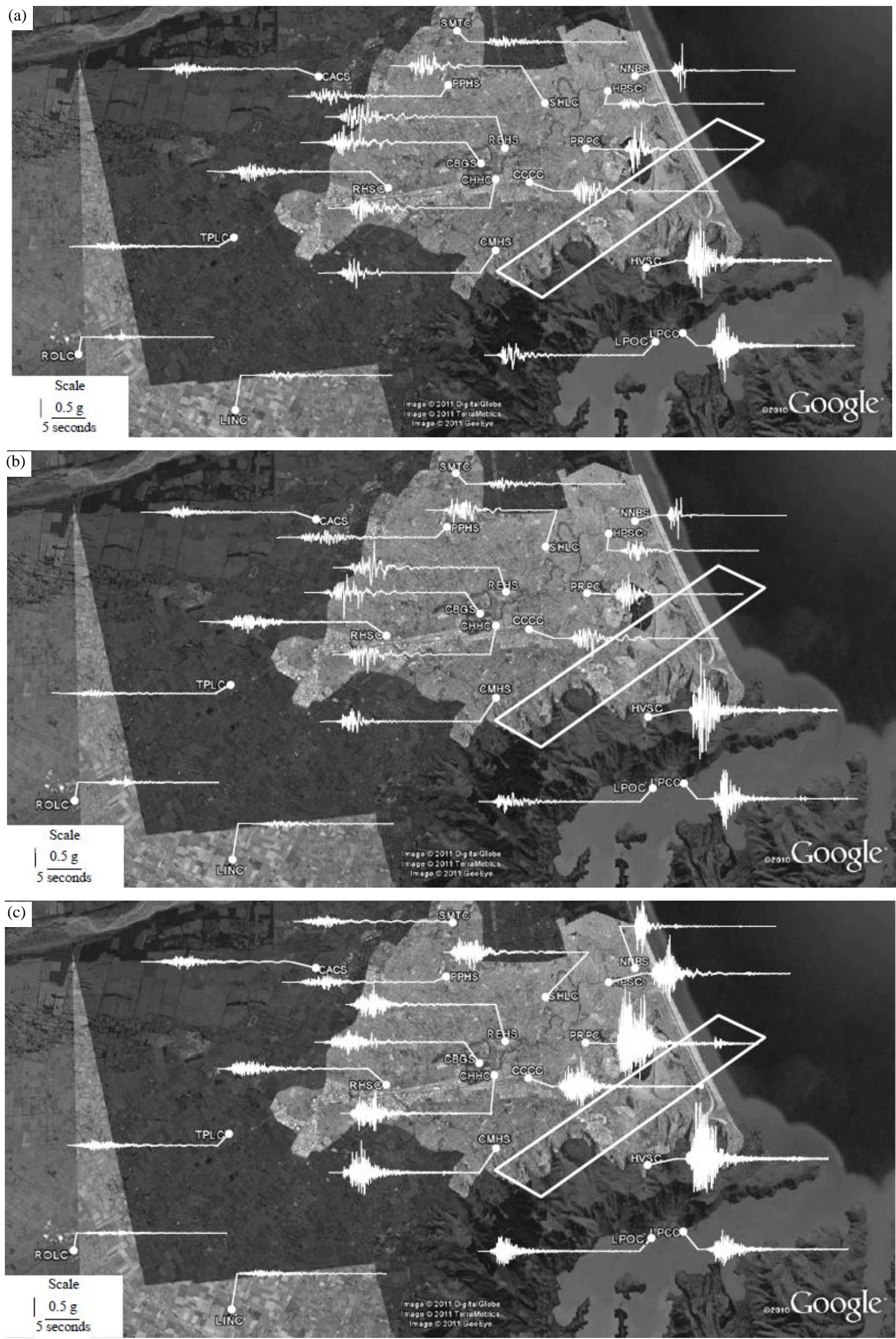

Figure 3: Observed acceleration time histories at various locations in the Christchurch region from the 22 February earthquake: (a) fault-normal horizontal; (b) fault-parallel horizontal; and (c) vertical components. 

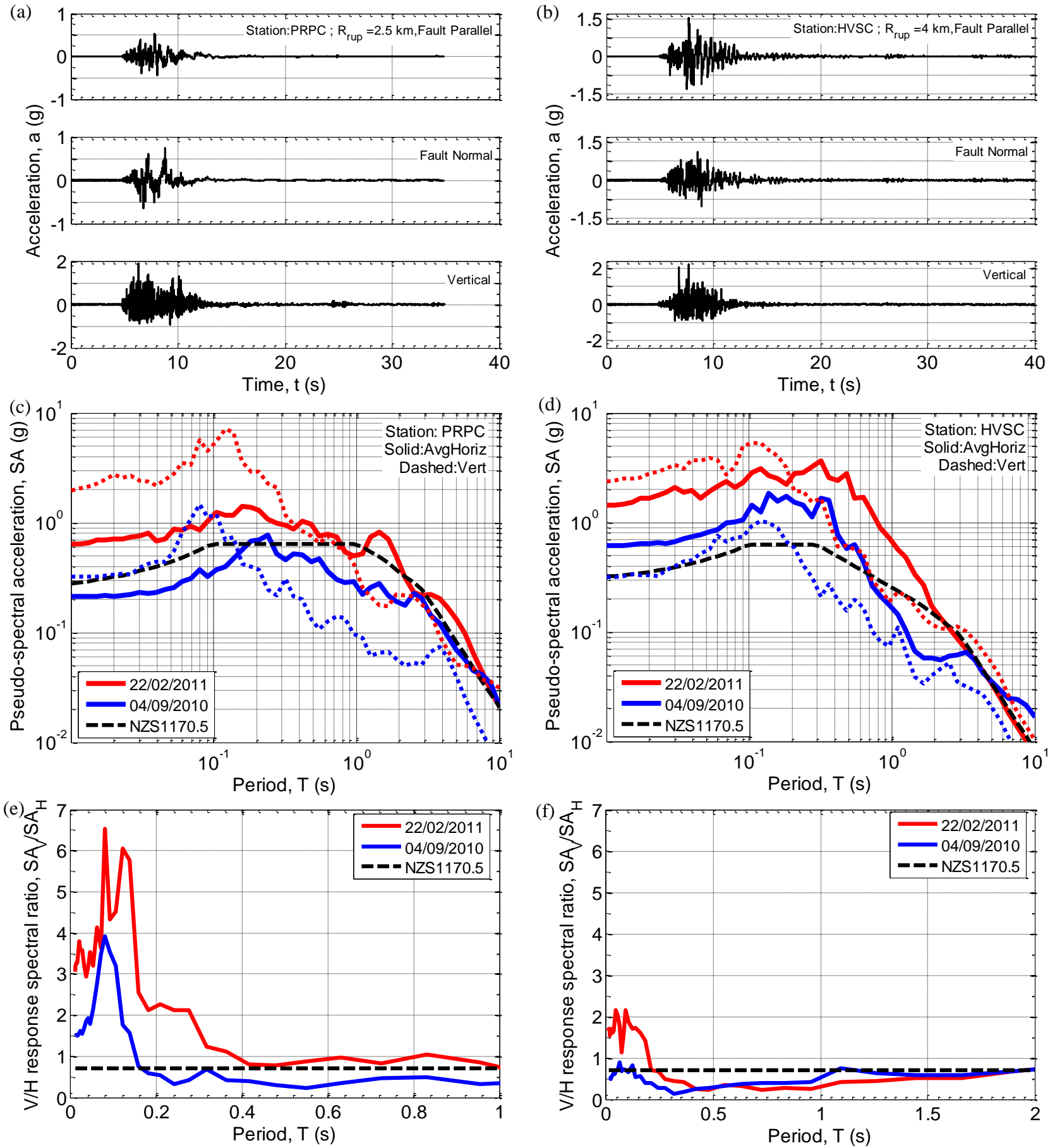

Figure 4: Extreme ground motions observed at Pages Road (PRPC) and Heathcote Valley (HVSC) in terms of acceleration time history, pseudo-acceleration response spectra, and vertical to horizontal spectral ratios. Note the different scale used for vertical acceleration time histories in Figure $4 a$ and Figure $4 b$ with that of the horizontal.

\section{EXTREME GROUND MOTIONS}

Examination of Figure 3 illustrates that very significant ground motion amplitudes were recorded in both the horizontal and vertical components at Pages Road (PRPC) and Heathcote Valley (HVSC), which are reproduced at a larger scale in Figure $4 \mathrm{a}$ and Figure $4 \mathrm{~b}$, respectively. In particular, maximum PGA's in the vertical component of $2.21 \mathrm{~g}$ and $1.88 \mathrm{~g}$ were observed at HVSC and PRPC, respectively. The vertical acceleration time histories at these two sites are also inferred to exhibit the so-called 'trampoline effect' [11, 12] caused by separation of surficial soil layers in tension, limiting peak negative vertical accelerations to approximately $-1 \mathrm{~g}$. As discussed subsequently, the ground motion at PRPC also experienced significant forward directivity effects which are evident in the long-period content of the fault normal component in Figure 4a.

Figure $4 \mathrm{c}$ and Figure $4 \mathrm{~d}$ illustrate the geometric mean horizontal and vertical pseudo-acceleration response spectra at PRPC and HVSC during both the Christchurch and 4 September 2010 Darfield earthquakes, and Figure 4e and Figure $4 \mathrm{f}$ illustrate the vertical-to-horizontal spectral ratios at these two sites in these two events. It can be clearly seen that the nature of the surface ground motion at each of these sites is similar in each of the two events, but fundamentally different between the two sites. For example, the response at PRPC is dominated by a relatively 'flat' response spectrum for high frequencies, indicative of nonlinear response in soil soft deposits. Furthermore, the vertical ground motion amplitude at high frequencies is particularly large (i.e. Figure 4e), indicating a soil deposit with high compressibility, that is, low 
P-wave velocity (e.g. clay, silt, peat). In contrast, the response at HVSC is characterised by large short period (i.e. $T<0.4 \mathrm{~s}$ ) ground motion with a rapid fall-off in spectral ordinates at longer periods (the exception being the increase for the Darfield earthquake at long periods due to the forward directivity pulse [13]). The vertical-to-horizontal spectral ratio is also notably lower than that at PRPC and only larger than 1.0 for very high frequencies. In-depth analysis of the strong ground motion at HVSC indicates a strong basin edge effect at this site due to its location near the Port Hills, resulting in constructive interference between direct $\mathrm{S}$-waves propagating through the underlying basin, and diffracted Rayleigh waves induced at the basin edge [13].

\section{NEAR SOURCE FORWARD DIRECTIVITY}

In the near-source region ground motions may exhibit forward directivity effects due to the rupture front and direction of slip being co-aligned with the direction toward the site of interest. While the finite fault model in Figure 2 does not provide information on the temporal evolution of rupture, based on the central location of the inferred hypocenter, the direction of slip is not well aligned with an elliptically inferred rupture front. As a result, it is expected that rupture directivity effects will only be important over a small area of the earth's surface, relative to other possible rupture scenarios [14]. This is in contrast to the 4 September 2010 Darfield earthquake, in which strike-slip rupture occurred bilaterally on the Greendale fault and forward directivity effects were significant for all locations in Christchurch city [13].

Figure 5a illustrates the three component velocity time history at Pages road (PRPC), where forward directivity effects can be
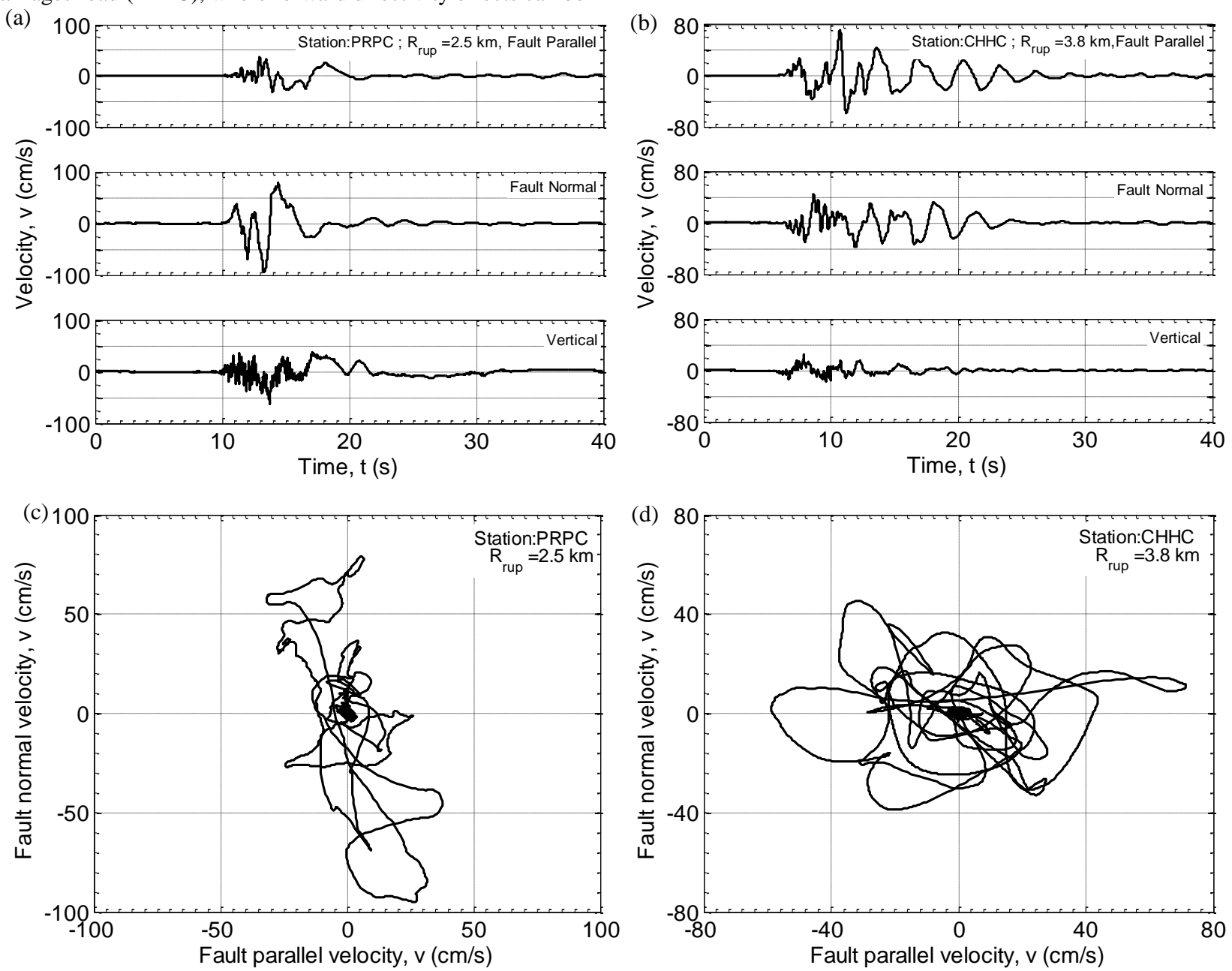

Figure 5: Velocity time histories and corresponding horizontal trajectory of fault normal and fault parallel velocity trajectory at Pages Road (PRPC) and Christchurch Hospital CHHC). 


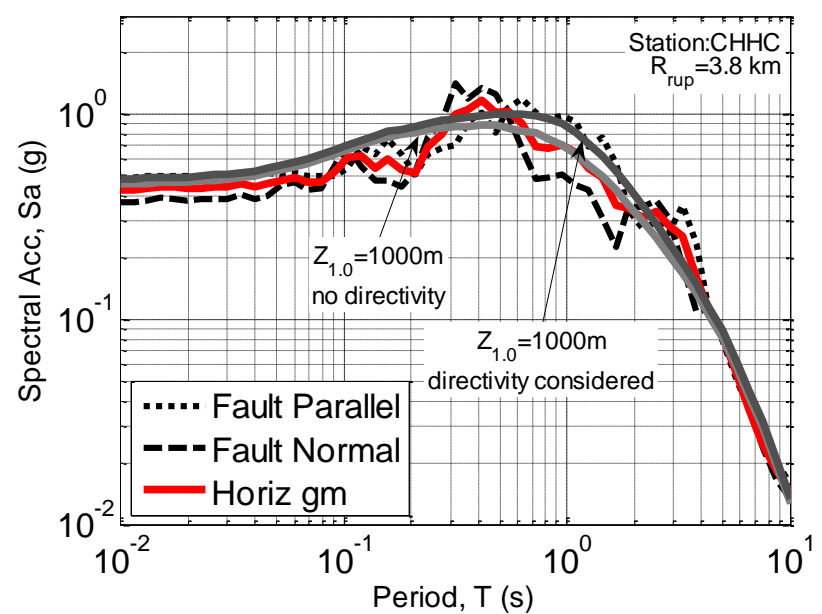

Figure 6: Empirically predicted effect of directivity on spectral amplitudes at Christchurch Hospital $(\mathrm{CHHC})$. The prediction shown is for the horizontal geometric mean.

\section{BASIN-GENERATED SURFACE WAVES}

As previously mentioned, Christchurch is located on a sedimentary fan deposit with the volcanic rock of Banks peninsula located to the south east. While specific mechanical and geometrical details of the predominant sedimentary basin layers are not well known, previous investigation has revealed the depth of gravel layers is in excess of $500 \mathrm{~m}$, with basement rock inferred to be at depths in excess of $2.0 \mathrm{~km}$ at various locations $[13,16]$.

Figure 7a provides a schematic illustration of the deep geology of the region along a plane trending south east to north west. Figure $7 \mathrm{a}$ also illustrates one possible ray path from the $M_{w} 6.3$ rupture in which seismic waves propagate up-dip and enter the sedimentary basin through its thickening edge. The large post-critical incidence angles of such waves cause reflections which lead to a waveguide effect in which surface waves propagate across the basin resulting in enhanced long period ground motion amplitudes and shaking duration [17]. Figure $7 \mathrm{~b}$ illustrates the fault-normal, fault-parallel, and geometric mean horizontal pseudo-response spectra at Christchurch Hospital (CHHC), located at a source-to-site distance of $R_{\text {rup }}=3.8 \mathrm{~km}$ on the footwall. Also shown in Figure $7 \mathrm{~b}$ is the predicted median response spectra for the site using the Bradley [10] empirical model for two different values of a proxy for basin depth. The Bradley [10] model is based on the Chiou and Youngs [18] model with New Zealand-specific modifications. Basin effects are accounted for in the model through the use of the parameter $Z_{1.0}$, which represents the depth to sediments with shear wave velocity, $V_{s}=1.0 \mathrm{~km} / \mathrm{s}$. For site class D conditions (a nominal 30-m average shear wave velocity of $V_{s, 30}=250 \mathrm{~m} / \mathrm{s}$ ) the default value of $Z_{1,0}$ is on the order of $300 \mathrm{~m} \mathrm{[18]}$. Figure $7 \mathrm{~b}$ illustrates that spectral amplitudes at CHHC for periods greater than 0.3 seconds are under-predicted using this default $Z_{1,0}$ value. Given the thickness of gravels in the Christchurch basin is known to be greater than $500 \mathrm{~m}$ implies that $Z_{1,0}$ would be significantly greater than $500 \mathrm{~m}$. Figure $7 \mathrm{~b}$ also illustrates the predicted spectral amplitudes, using a value of $Z_{1,0}=1000 \mathrm{~m}$, where it can be seen that the empirical prediction of long period spectral amplitudes is significantly increased, compared with those using $Z_{1.0}=300 \mathrm{~m}$, in line with the observed amplitudes.
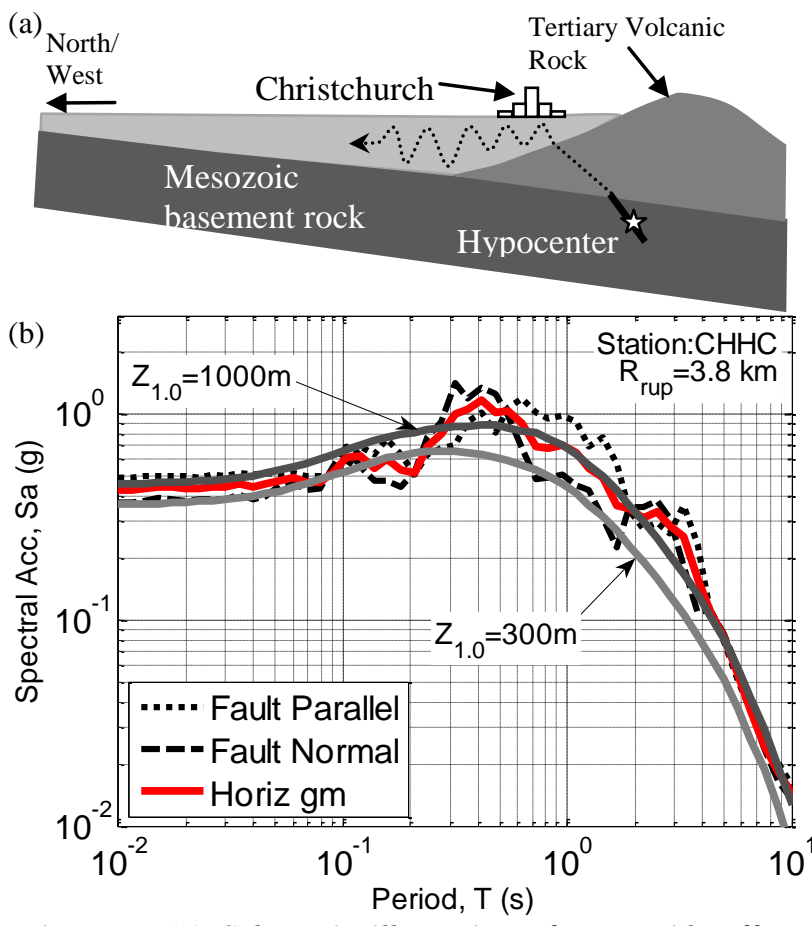

Figure 7: (a) Schematic illustration of waveguide effects occurring in the sedimentary basin underlying Christchurch (not to scale); and (b) influence of basin depth on pseudo-spectral acceleration ordinates predicted empirically compared with that observed at Christchurch Hospital (CHHC). The prediction shown is for the horizontal geometric mean.

The increase in amplitude of horizontal ground motion at long periods illustrated at Christchurch hospital (CHHC) was also observed at numerous other locations in the region as depicted at four locations in Figure 8. At close source-to-site distances clearly discerning surface wave contribution is not trivial due to the overlap in time of the first surface wave arrivals and scattered S-waves. Both Papanui (PPHS) and Styx Mill (SMTC) however illustrate several long period oscillations subsequent to the majority of S-wave arrivals. The significant amplitude Rayleigh surface waves in the vertical component at SMTC are particularly noticeable, and are also observed at other strong motion stations (i.e. Figure 3c). The significance of basin-induced surface waves becomes more visible and predominant as the distance from the causative fault increases, both as a result of the different wave propagation velocities of the body and surface waves (so they arrive at different times and are easier to visually bracket), and also because of the fact that body waves geometrically attenuate at a higher rate $\left(R^{-1}\right)$ than surface waves $\left(R^{-1 / 2}\right)$ with distance. As a result it can be seen in Figure 8 that, at both Templeton (TPLC) to the west of Christchurch, and Kaiapoi to the north, the duration and also amplitude of the surface waves relative to body waves significantly increases. At KPOC in particular, it can be seen that despite being $20 \mathrm{~km}$ from the causative fault, high frequency ground motion occurs followed by significant surface wave amplitudes with PGV's up to 20 $\mathrm{cm} / \mathrm{s}$. The large amplification of high frequency ground motion followed by surface waves was also observed at KPOC during the Darfield earthquake [13], and combined with the very loose soil deposits, indicates how liquefaction occurred in this region during both the earthquakes, despite source-to-site distances of $R_{r u p}=27.6 \mathrm{~km}$ and $17.4 \mathrm{~km}$, respectively. 
(a)

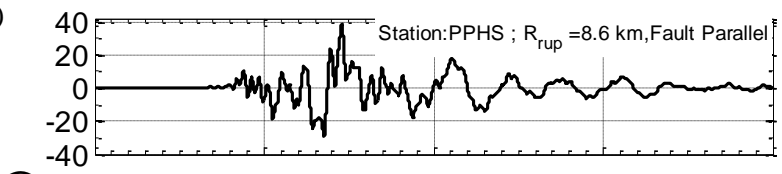

है

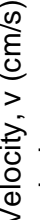

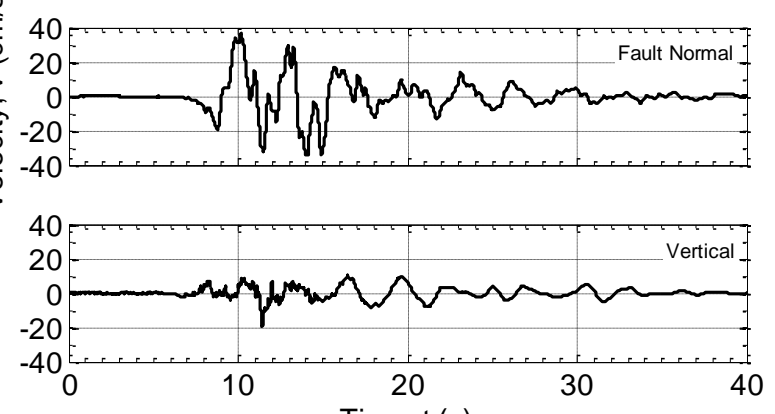

(b)
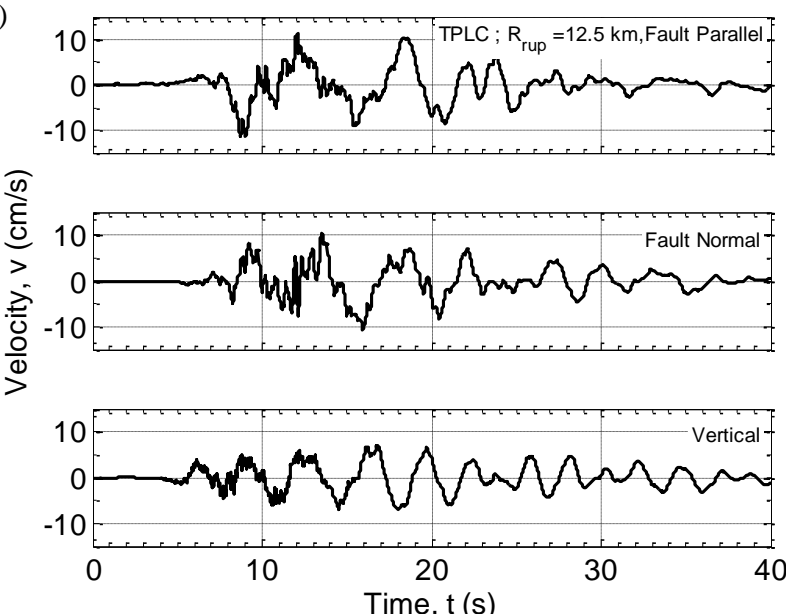

(b)

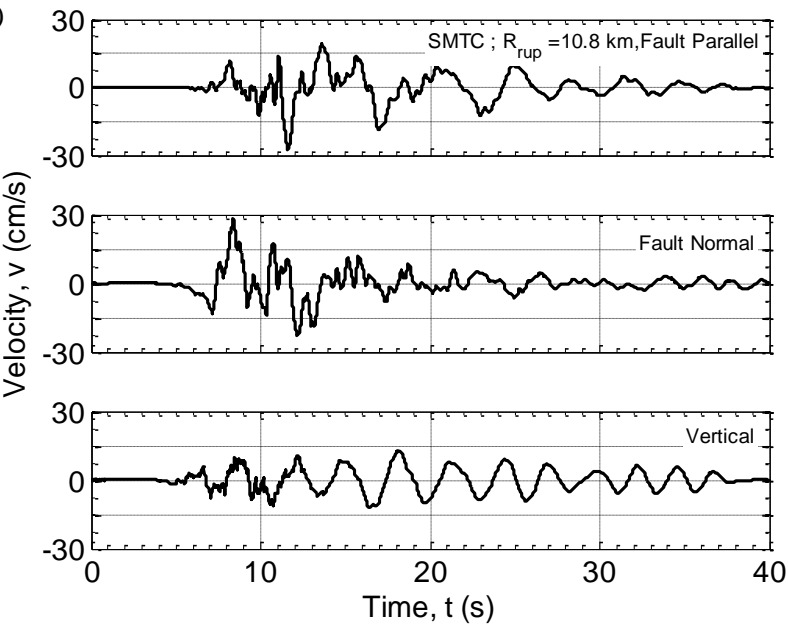

(d)

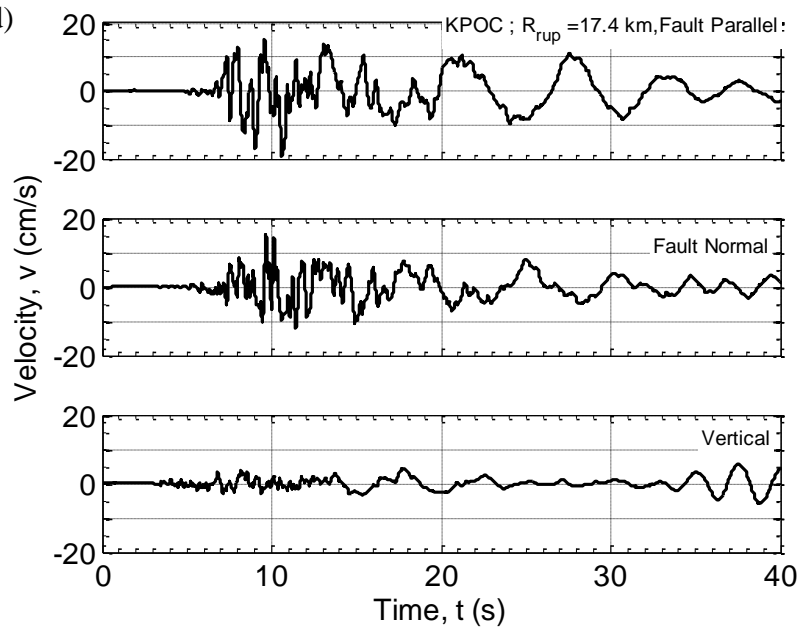

Figure 8: Velocity time histories illustrating the significance of basin-generated surface waves: (a) Papanui (PPHS); (b) Styx Mill (SMTC); (c) Templeton (TPLC); and (d) Kaiapoi (KPOC).

\section{NONLINEAR NEAR-SURFACE RESPONSE AT SOIL SITES}

\section{Near-surface response at Lyttelton Port}

When interpreting the observed ground motions in Figure 3, it is worth recalling that only the Lyttelton Port (LPCC) station to the southeast of Christchurch is located on engineering bedrock (i.e. site class B). Stations HVSC and LPOC located near the edge of the Port Hills rock outcrop are site class C, while all remaining stations are situated on the Christchurch sedimentary basin and are predominantly site class D, with those having (identified) soft soil layers deemed site class E. Unfortunately at present the site characterisation of strong motion stations in the Christchurch region, and New Zealand in general, is relatively poor with the above site classes determined from geological maps, and details such P- and Swave velocity, SPT, and CPT data not available. Clearly, obtaining such information is a high priority to rigorously understand the site-specific features of observed ground motions, and is the focus of immediate studies. Nevertheless, a wealth of insight can still be obtained from inspection and analysis of the observed ground motions.

Direct observation of the difference between soil and rock sites, and the impact of nonlinear response can be made by comparing the ground motions observed at LPCC and LPOC located at Lyttelton Port approximately $1 \mathrm{~km}$ apart. The LPCC instrument is located on engineering bedrock, and the site conditions at LPOC are inferred as a relatively thin $(\sim 30 \mathrm{~m})$ colluvium layer comprised primarily of silt and clay (J. Berrill, pers. comm.). In addition to a comparison of the acceleration time histories in Figure 3, Figure 9 illustrates the pseudo-acceleration response spectra of the geometric mean horizontal and vertical ground motion components at the two sites. It can be seen that the observed horizontal ground motion at the LPOC site has significantly lower high frequency ground motion amplitude, longer predominant period (Table 1), larger peak ground velocity, and larger significant duration, relative to LPCC, inferred as the result of nonlinear response of the surficial soils. In contrast to the significant difference in horizontal ground motion, it can be seen that there is relatively little difference between the vertical ground motion at LPCC and LPOC, with peak vertical accelerations of $0.51 \mathrm{~g}$ and $0.39 \mathrm{~g}$, respectively.

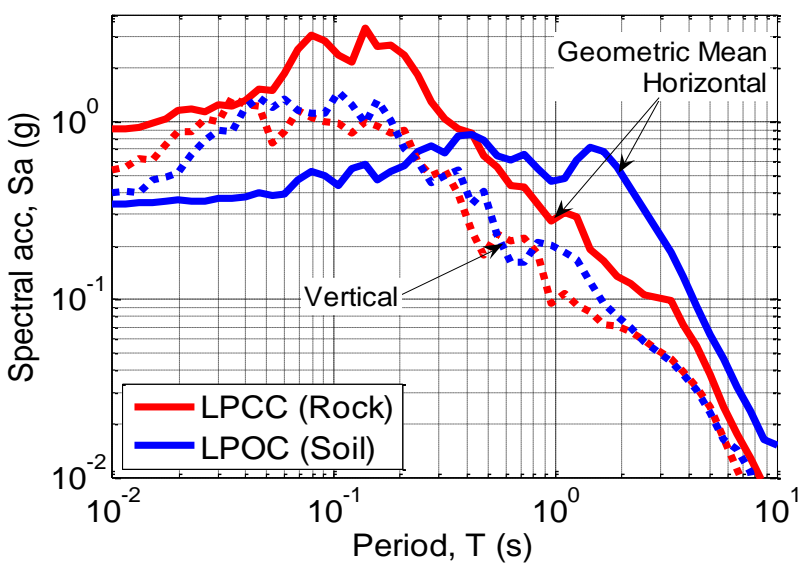

Figure 9: Comparison of geometric mean horizontal and vertical response spectra observed at two stations in Lyttelton Port, one on outcropping rock (LPCC), the other on soil (LPOC). 


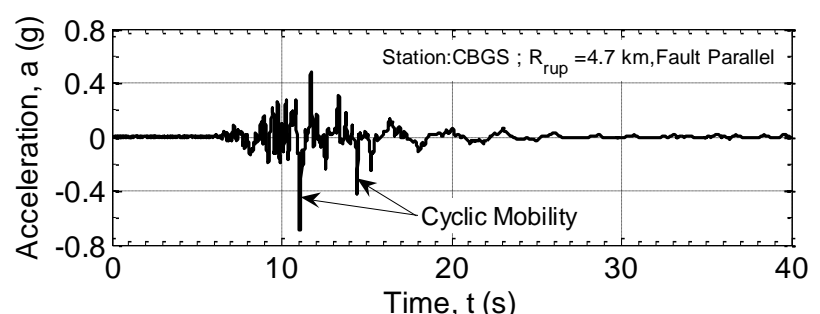

Figure 10: 'Spikes' in acceleration time histories resulting cyclic mobility in underlying liquefied soils.

\section{Evidence of liquefaction}

One of the major causes of damage in the $M_{w} 6.3$ Christchurch earthquake resulted from the severity and spatial extent of liquefaction in residential, commercial and industrial areas. The horizontal components of acceleration depicted in Figure $3 \mathrm{a}$ and Figure $3 \mathrm{~b}$ show clear evidence of liquefaction phenomena in the central business district and eastern suburbs which are located in the near-source region beyond the up-dip projection of the fault plane. For clarity, an example ground motion for Canterbury Botanic Garden (CBGS) is shown in Figure 10, for which the acceleration 'spikes' due to cyclic mobility are explicitly annotated. Such phenomena occur as a result of the rapid increase in shear stiffness and strength during large shear displacement in soils as a result of volumetric dilation, which consequently allows for the propagation of high frequency ground motion.

In the central business district (i.e. REHS, CBGS, CHHC, CCCC), Cashmere (CMHS) and Shirley (SHLC), evidence of liquefaction at depth is inferred based on the manifested reduction in high frequency content of ground motion following several seconds of S-wave arrivals, and the subsequent acceleration 'spikes'. In the eastern suburbs (i.e. PRPC, HPSC, NNBS), the picture is somewhat more complex. The ground motion at Pages road (PRPC) also has some of the characteristics discussed above, but in addition exhibits very high accelerations in the fault-normal and vertical directions, which likely result from both surficial soil and source effects, due to its proximity to the up-dip projection of the slip asperity (as previously noted). The ground motion at North New Brighton (NNBS) exhibits several seconds of cyclic mobility before an abrupt reduction in acceleration amplitude resulting in a very short significant duration of 2.4 seconds (Table 1 ). The ground motion observed at Hulverstone Drive (HPSC) is also of interest due to the relatively small horizontal component acceleration amplitudes compared with what might be expected at such a near-source location (including observed shaking at nearby stations), and relative to its high vertical accelerations.

No significant signs of liquefaction are evident in the ground motions recorded to the west of those discussed above, which results from three factors: (i) a reduction in amplitude of ground shaking; (ii) a change in surficial soil characterization; and (iii) an increase in water table depth as noted previously. Given the observed spatial extent of liquefaction in the Darfield earthquake [19], in which the majority of this western region was unaffected by liquefaction, despite been subjected to generally stronger shaking than the eastern regions (where liquefaction was prevalent), it can be logically concluded that the character and in-situ state of the soils are the predominant reason for the absence of liquefaction in the western Christchurch region [8].

\section{VERTICAL GROUND MOTION}

As previously noted with reference to Figure $3 c$, large ground motions were observed in the vertical component at various locations in this earthquake. Such large vertical accelerations can be understood physically, because the majority of strong motion stations are located on soil sites, and for soil sites in sedimentary basins large vertical accelerations at near-source locations can result from the conversion of inclined SV-waves to P-waves at the sedimentary basin interface which are subsequently amplified and refracted towards vertical incidence due to the basin P-wave gradient [20]. Secondly, the relatively steep dip of the fault plane $\left(\delta=69^{\circ}\right)$, and up-dip rupture propagation also likely resulted in a large component of fault slip oriented in the vertical direction.

Figure 11 illustrates the ratio of peak vertical acceleration and peak horizontal acceleration observed at the near-source strong motion sites in the Christchurch earthquake. For comparison, the empirical model of Bozorgnia and Campbell [21] is also shown. It can be seen that peak vertical-tohorizontal ground acceleration ratios of up to 4.8 were observed. The peak vertical-to-horizontal ground acceleration ratios show a rapid decay with source-to-site distance and it can be seen that the observed ratios compare favourably with the Bozorgnia and Campbell empirical model for source-tosite distances beyond $5 \mathrm{~km}$, but significantly under-predict the ratios at closer distances. In Figure 11, data are also differentiated by whether liquefaction was observed (as discussed previously). It can be seen that almost all strong motion records at distances less than $5 \mathrm{~km}$ show liquefaction evidence (the exception being HVSC). At the aforementioned sites (with source-to-site distances are less than $5 \mathrm{~km}$ ), the large peak vertical-to-horizontal ground acceleration ratios observed are interpreted to be the result of significant nonlinear soil behaviour (including liquefaction) which generally results in more of a reduction in peak horizontal accelerations than peak vertical accelerations (e.g. as seen in Figure 9).

To explore the results in Figure 11 in more detail, and provide addition insight, Figure 12a illustrates the geometric mean horizontal pseudo-acceleration response spectra at PRPC, $\mathrm{CHHC}$ and RHSC, and Figure $12 \mathrm{~b}$ the corresponding verticalto-horizontal ratios. As has been commonly observed in numerous other studies, it can be seen that the vertical-tohorizontal (V-to-H) spectral ratio is largest at high frequencies with values that can be significantly greater than 1.0 , and tends to reduce rapidly for vibration periods greater than $T=0.1 \mathrm{~s}$, and as a function of source to site distance (i.e. from Table $1, R_{\text {rup }}=2.5 \mathrm{~km}, 3.8 \mathrm{~km}$, and $6.5 \mathrm{~km}$ for PRPC, CHHC, and RHSC, respectively). Figure $12 \mathrm{c}$-Figure $12 \mathrm{f}$ illustrate the $\mathrm{V}$-to-H spectral ratios for four different vibration periods, $T=0.0,0.1,0.2$, and $0.3 \mathrm{~s}$ as a function of source-to-site distance for both the 22 February 2011 Christchurch and 4

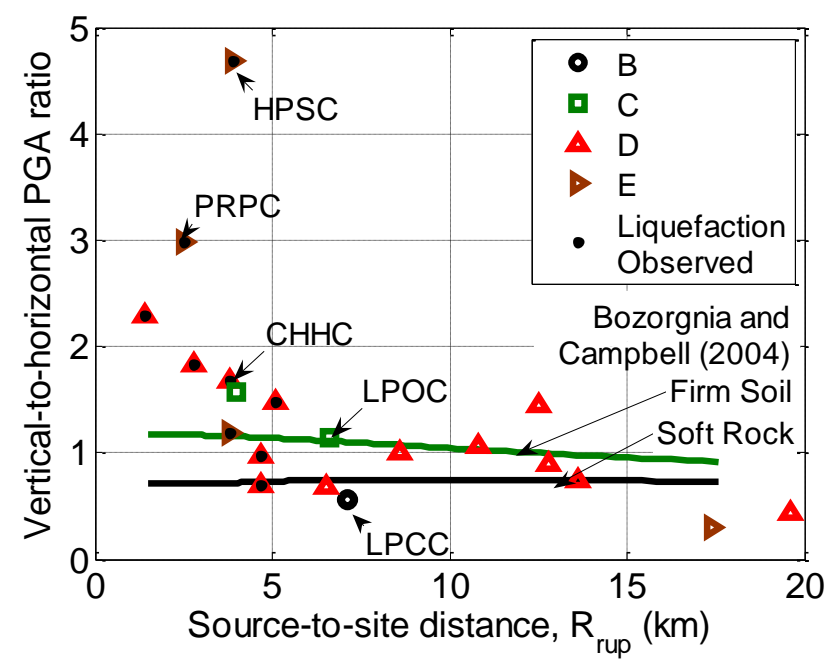

Figure 11: Observed vertical-to-horizontal peak ground acceleration ratios as a function of source-to-site distance in comparison with the empirical equation of Bozorgnia and Campbell [21]. Data are differentiated by site class as well as evidence of liquefaction. 
September 2010 Darfield earthquakes. Also shown for comparison is the empirical model of Bozorgnia and Campbell [21], and the prescribed ratio of 0.7 for the development of vertical design spectra in NZS1170.5 [9]. Firstly, it can be clearly seen that $\mathrm{V}$-to-H ratios above 1.0 are frequently observed for distances up to $R_{\text {rup }}=40 \mathrm{~km}$ in both these events (as well as other historical earthquakes worldwide [21]), and hence the code prescription of 0.7 is, without question, significantly un-conservative. Secondly, it can be seen that while there is significant scatter in the observed ratios, the Bozorgnia and Campbell empirical model is able to capture the overall trends in the observations, except for $R_{r u p}<10 \mathrm{~km}$

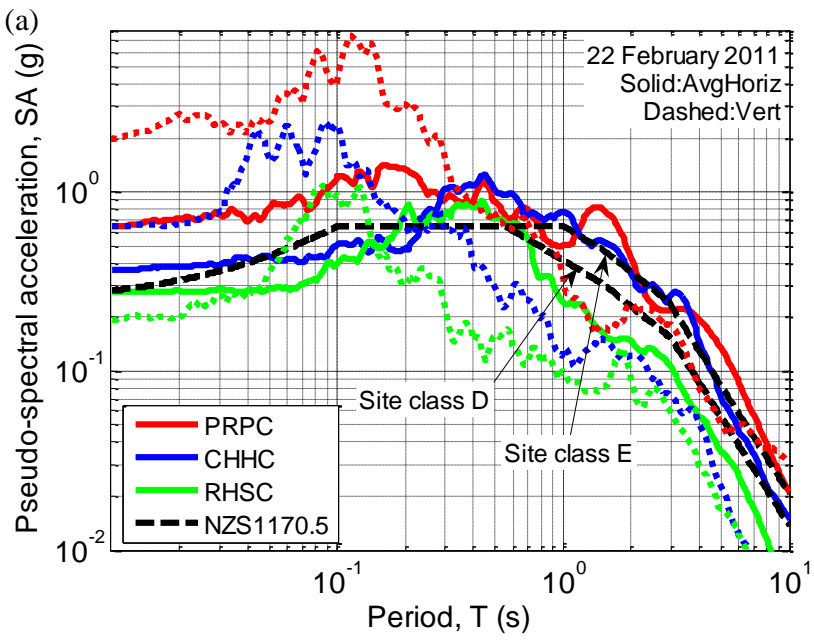

(c)
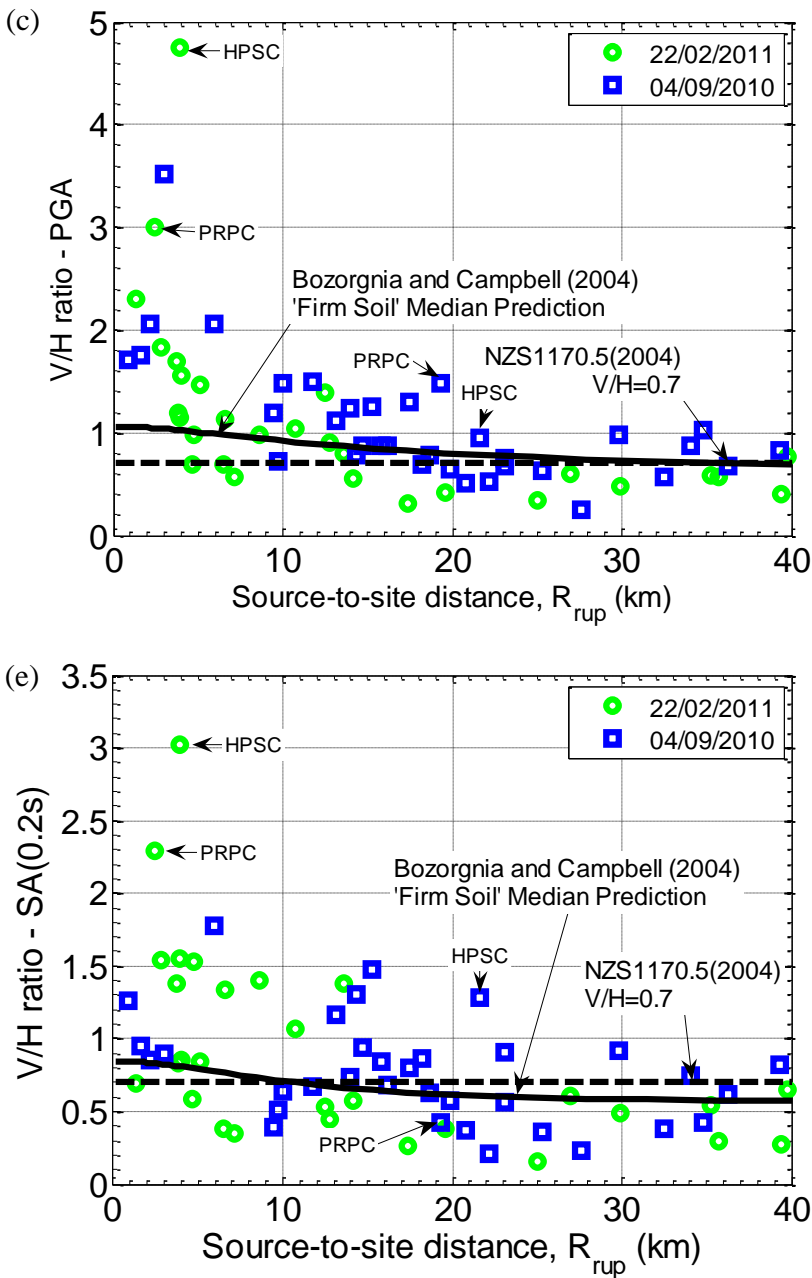

for which it underestimates the observed ratios. Comparison of the observations from the Darfield and Christchurch earthquakes also illustrates that the ratios, on average, are principally a function of source-to-site distance and there is no evidence for a systematic differences between the two events due to their different magnitude and style of faulting. This lack of average dependence the seismic source features is consistent with that of Bozorgnia and Campbell [21]. Comparison of the ratios observed at the same station in the two different events (annotated in the figures for PRPC and HPSC) illustrates that there is some systematic site effect, for example, HPSC is always above the average prediction, but

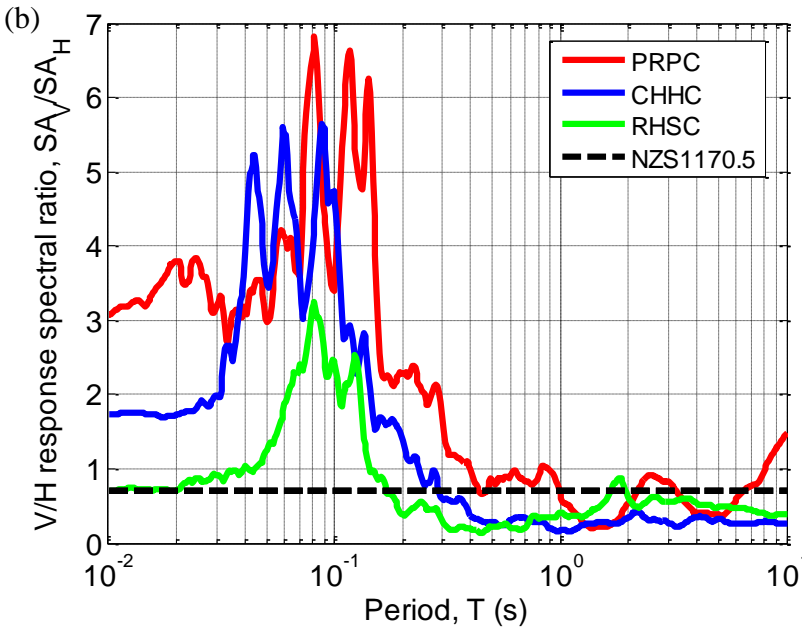

(d)
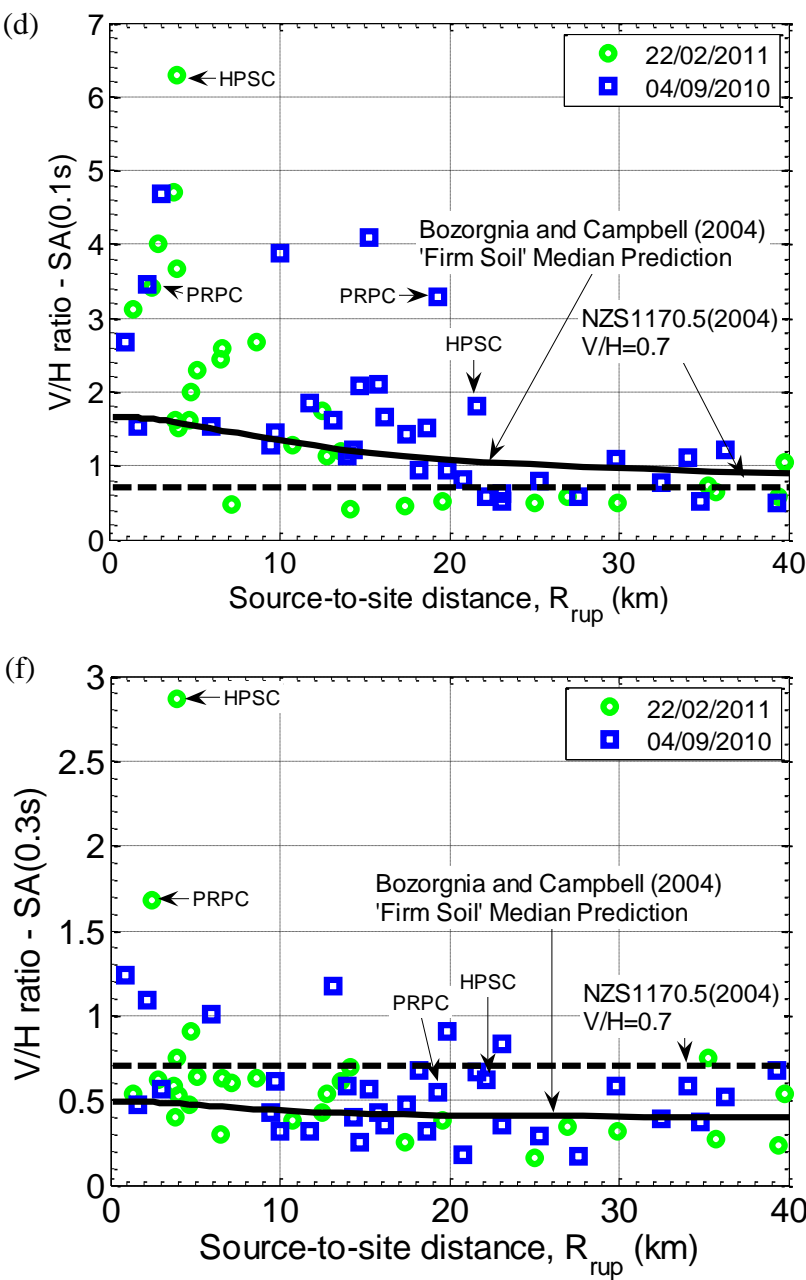

Figure 12: Vertical ground motion response spectral amplitudes observed: (a)-(b) Example geometric mean horizontal and vertical response spectra and their vertical-to-horizontal ratio; (c)-(e) vertical-to-horizontal response spectral ratios for $T=0.0-0.3 s$ as a function of distance observed in the 4 September 2010 Darfield and 22 February 2011 Christchurch earthquakes and comparison with the empirical prediction of Bozorgnia and Campbell [21]. 
this is not always the case for PRPC with the ratio for $T=0.2 \mathrm{~s}$ well above the prediction in the Christchurch earthquake, but below the prediction in the Darfield earthquake. Given that vertical ground motion is only significant at very high frequencies, then it is expected to be strongly correlated with near-surface P-wave velocity structure, and some of the fluctuations observed in Figure 12 are likely the result of variability in the amplitude of the horizontal ground motion on the V-to-H ratio (due to nonlinearities for example).

The above discussions serve to illustrate that the large number of observed strong vertical ground motions in the 22 February 2011 Christchurch earthquake is simply a result of a larger number of recordings at very small source-to-site distances relative to the Darfield earthquake (e.g. 15 records within $10 \mathrm{~km}$ in the Christchurch earthquake as compared with 8 in the Darfield earthquake), rather than any specific source effect during rupture in the Christchurch earthquake. Finally, as horizontal ground motion amplitudes within Christchurch city in the Christchurch earthquake were larger than those from the Darfield earthquake (elaborated upon subsequently), then nonlinear shear deformation of soils which results in a reduction of tangent shear modulus, and therefore the ability to propagate high frequency ground motion, was more significant in the 22 February event. Nonlinear shear deformation on the other hand does not have as significant an effect on the compressibility of soil, which is related to Pwave velocity, and hence vertical ground motion amplification. The significant effect of nonlinear site response on horizontal ground motion, yet minor effect on vertical ground motion, was clearly illustrated in Figure 9.

\section{COMPARISON OF OBSERVATIONS WITH EMPIRICAL GROUND MOTION PREDICTIONS FOR HORIZONTAL COMPONENTS}

To provide a more complete analysis of the ground motions discussed in the previous sections with respect to physical phenomena this section compares the observed ground motions with empirical ground motion predictions. A rigorous assessment of the efficacy of various empirical ground motion prediction equations (GMPEs) is not attempted, and the aim is merely to identify ground motions which have intensity measures deviating from such GMPEs, and subsequently an attempt to explain such deviations based on previous physical phenomena-oriented discussions.

\section{Pseudo-acceleration response spectra}

Figure 13 illustrates the pseudo-acceleration response spectra (SA) amplitudes of ground motions recorded within $50 \mathrm{~km}$ of the casual faults in the Darfield earthquake at periods of $T=0.0,0.2,1.0$ and $3.0 \mathrm{~s}$. The observations are compared with the empirical SA GMPE developed by Bradley [10], which is a NZ-specific modification of the Chiou and Youngs [18] and Chiou et al. [22] models. For each of the different vibration periods considered, the median, $16^{\text {th }}$ and $84^{\text {th }}$ percentiles of the prediction for site class D conditions is shown. Mixed-effects regression [23, 24] was utilized in order to determine the inter- and intra-event results for each vibration period. The value of the normalized inter-event residual $(\eta)$ is also shown in the inset of each figure.

The results of Figure 13 illustrate that the Bradley [10] GMPE is able to capture the source-to-site distance dependence of the observations with good accuracy. The inter-event term, which can be viewed as an overall bias of the amplitudes predicted relative to those observed, indicates that the model has very small bias for vibration periods of $\mathrm{T}=0.0$ and $0.2 \mathrm{~s}$ (i.e. $\eta=$ 0.034 and -0.037 , respectively), but that there is a anderprediction of $\mathrm{SA}(1.0)$ amplitudes for a handful of ground motions at source-to-site distances less than $10 \mathrm{~km}$, and also a notable under-prediction of $\mathrm{SA}(3.0)$ amplitudes for all distances (i.e. $\eta=1.283$ ). The good prediction of high frequency ground motion (i.e. PGA and $\mathrm{SA}(0.2)$ ) indicates that the source rupture didn't have a significantly different stress drop than what would be expected for such events. Hence, based on the previously discussed observations it can be logically concluded that the under-prediction at medium-tolong vibration periods is likely primarily a result of the fact that the model does not explicitly account for the large longperiod ground motion resulting from basin-generated surface waves (as previously noted the basin depth parameter, $Z_{1.0}$, is presently set based on the near surface shear wave velocity, $V s 30$, due to a lack of data on basin depths for various locations in New Zealand), or near-source forward directivity. As was previously noted with reference to Figure 6 and Figure 7 , the explicit consideration of these effects can help to improve the prediction of the model at long periods, which is an active area of current research.

Another possible reason for the under-prediction of ground motion at long periods is the additional amplification of long period motion resulting from highly nonlinear soil behaviour. While the empirical model attempts to account for soil nonlinearity, clearly this is achieved in a highly simplified manner, and there is a limited number of strong motions previously recorded on soft soil deposits. While it is often noted that highly nonlinear behaviour also results in an increase in hysteretic damping it should be borne in mind that because of the short duration of shaking (as elaborated below), there was generally not a large amount of time for hysteretic damping to have a significant effect on the peak response amplitude.

Finally, Figure 13 also annotates various strong motion stations which lie outside the $16^{\text {th }}$ and $84^{\text {th }}$ percentiles of the empirical prediction, and which have been mentioned in previous sections. It can be seen, for example, that the short period spectral amplitudes observed at Heathcote Valley (HVSC) are significantly above those predicted (for site class $\mathrm{C}$, even though only the site class D prediction is shown) as a result of basin edge effects [13]. For SA(1.0) and SA(3.0), in particular it can be seen that all of the notable underpredictions occur for ground motions within $10 \mathrm{~km}$, and for which as previously noted, significant basin effects were evident.

\section{Significant duration}

The duration of strong motion is also important if strong motion amplitude is sufficient to cause nonlinear response of soil deposits and/or structures. Figure 14 illustrates the 5$75 \%$ and $5-95 \%$ significant durations $\left(D_{\mathrm{s} 575}\right.$ and $D_{\mathrm{s} 595}$, respectively) of ground motion observed at stations within 50 $\mathrm{km}$ of the causative fault. It is worth noting that anecdotally the $5-75 \%$ and $5-95 \%$ definitions of significant durations can be considered to approximately represent the durations the majority of energy associated with body-wave arrivals and body- plus surface-wave arrivals, respectively [25].

The empirical prediction of Bommer et al. [26] was utilized in the comparisons with the observed durations. It can be seen in Figure 14 that for both measures of duration, the observations are on average in good agreement with the observations, with inter-event residuals of $\eta=-0.064$ and -0.179 for $D_{s 575}$ and $\mathrm{D}_{\mathrm{s} 595}$, respectively. However, for $\mathrm{D}_{\mathrm{s} 575}$ in particular, it can be seen that for ground motions within approximately $10-15 \mathrm{~km}$, the ground motion duration at site class D sites (which the prediction is shown for), tend to be larger than the median

of the prediction, although less than the $84^{\text {th }}$ percentile, while in contrast the durations tend to be below average beyond this distance. 
(a)

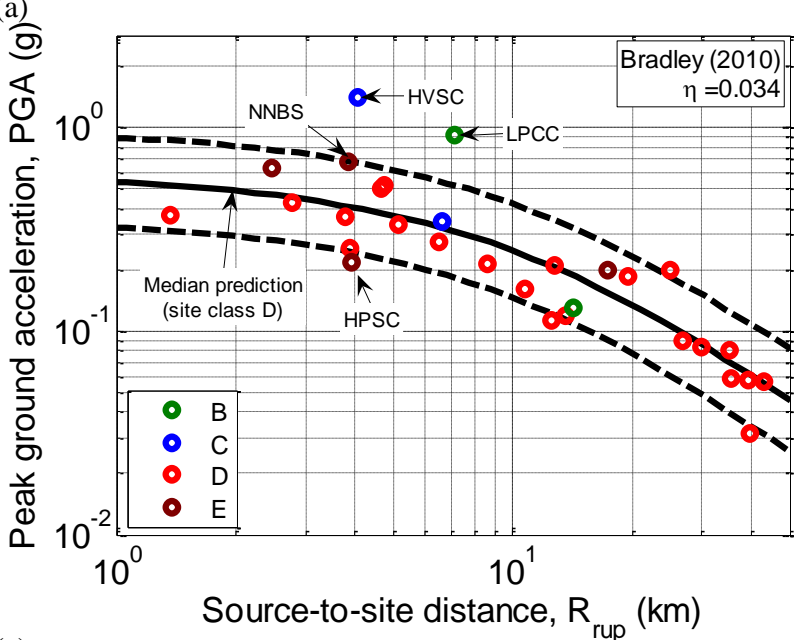

(c)

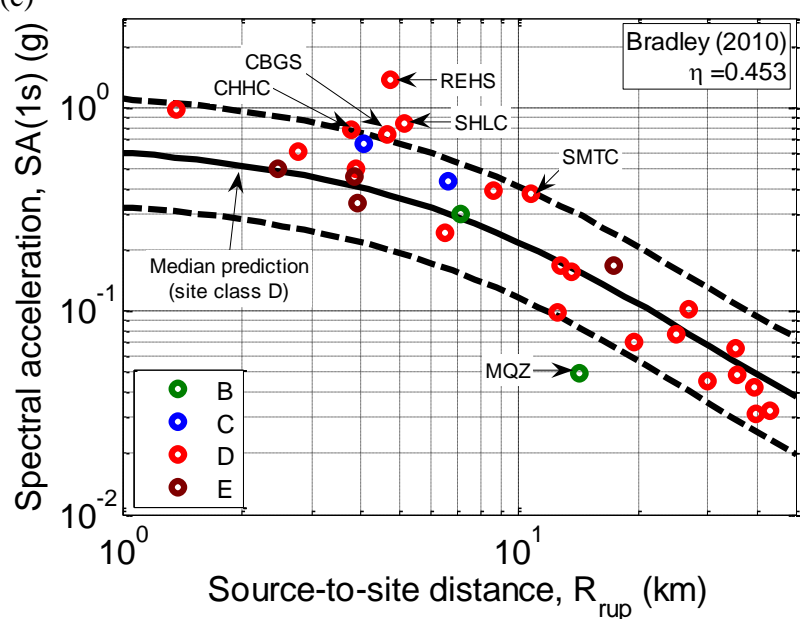

(b)

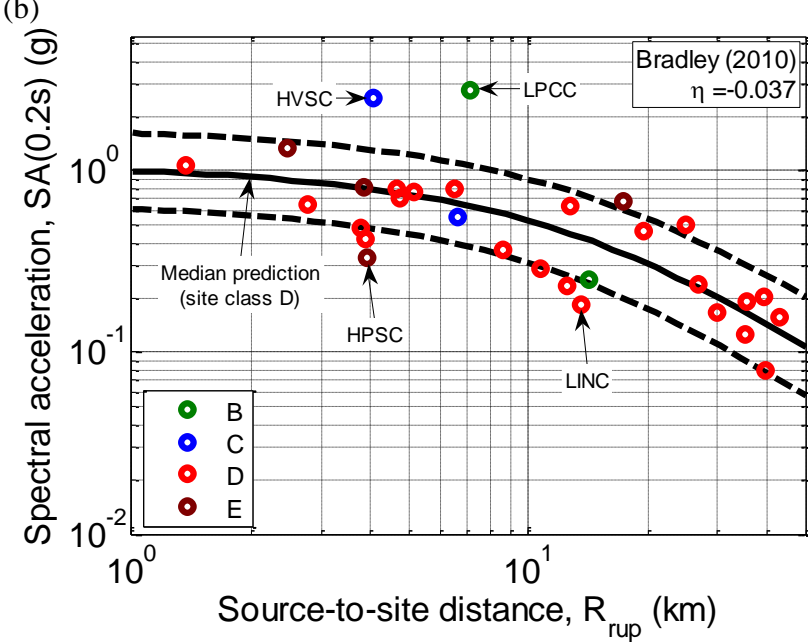

(d)

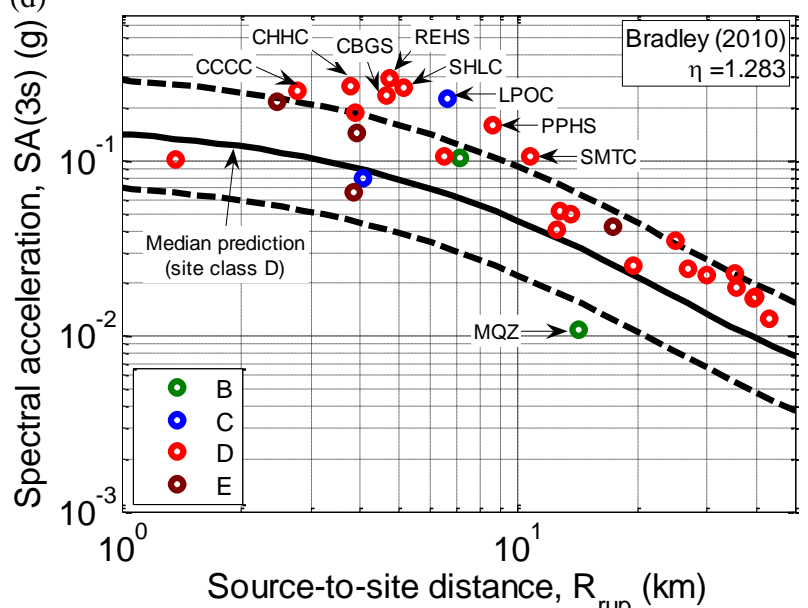

Figure 13: Comparison of pseudo-acceleration response spectral amplitudes observed with empirical prediction equations: (a) PGA; (b) SA(0.2s); (c) SA(1s); and (d) SA(3s).

(a)

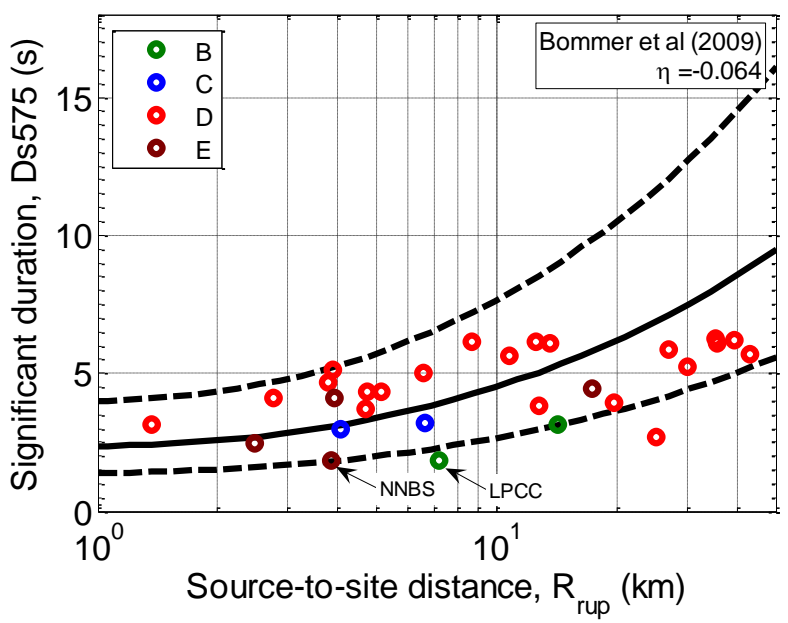

(b)

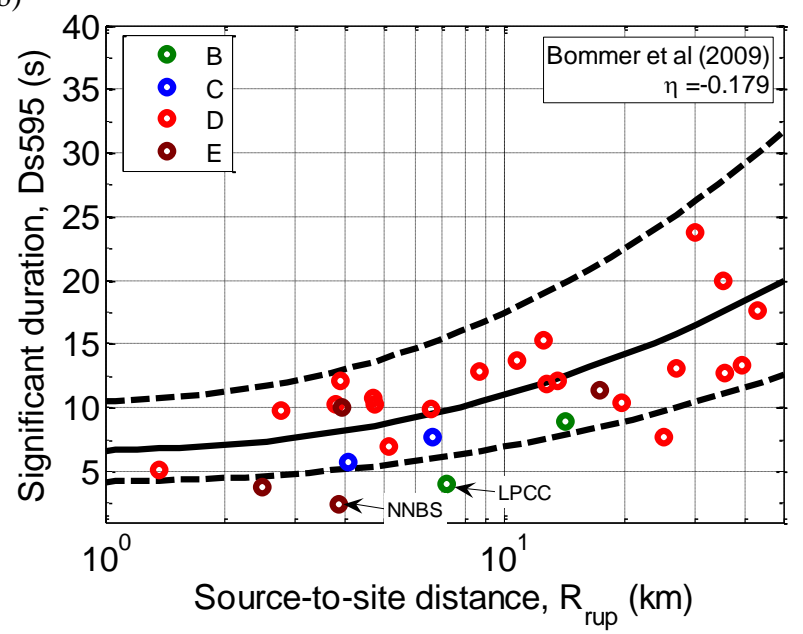

Figure 14: Comparison of observed ground motion significant direction with empirical prediction equations: (a) 5-75\% significant duration; and (b) 5-95\% significant duration.

It is speculated that this maybe the result of the rupture having a shorter than typical source duration (which would mean that motions at all distances, on average, would be below the $D_{s 575}$ prediction), but that within the near-source region (in this case $R_{\text {rup }}<15 \mathrm{~km}$ ) significant nonlinear behaviour leads to an increase in long period nature of the surface motion and consequently strong motion duration. For the 5-95\% duration it can be seen that there is no clear bias at the larger source-to- site distances, likely a consequence of the basin-generated surface waves (as discussed with reference to Figure 8).

\section{GROUND MOTION INTENSITY IN THE CENTRAL BUSINESS DISTRICT (CBD)}

The Christchurch earthquake caused significant damage to commercial structures in the CBD, with a large portion still (at 

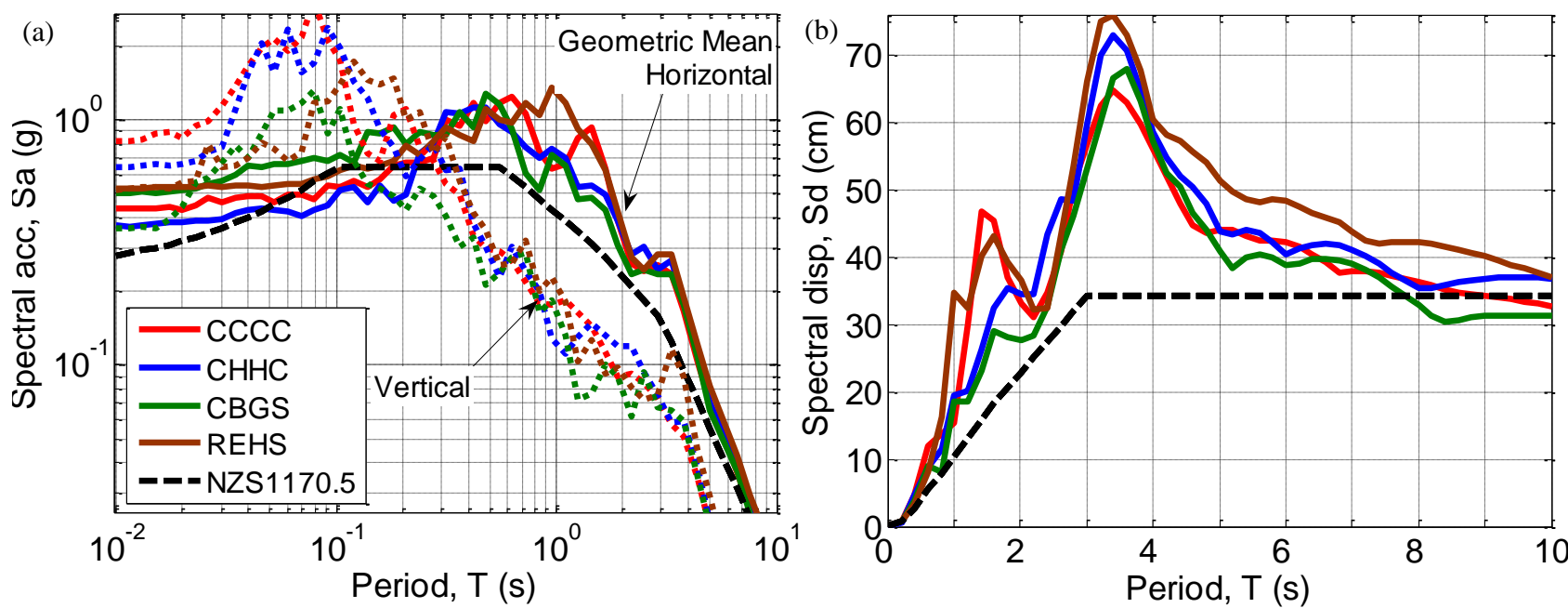

Figure 15: Comparison of response spectra from four strong motion stations located in the Christchurch central business district: (a) horizontal and vertical pseudo-acceleration response spectra; and (b) horizontal displacement response spectra.

the time of writing) prohibited while an estimated 1,000 structures (of various typologies, construction materials and age) are being demolished. The complete collapse of the Pine Gould Corporation (PGC) and Canterbury Television (CTV) buildings also lead to the majority of the 182 casualties [1].

Figure $15 \mathrm{a}$ and Figure $15 \mathrm{~b}$ illustrate the pseudo-acceleration and displacement response spectra of four strong motion stations (CCCC, CHHC, CBGS, REHS) located in the CBD region. Despite their geographic separation distances (relative to their respective source-to-site distances) it can be seen that the characteristics of the ground motion observed at these locations is relatively similar. This is particularly the case for long-period ground motion amplitudes, which have longer wavelengths and therefore are expected to be more coherent. On the other hand, at short vibration periods there is more of a discrepancy in seismic intensity due to a shorter wavelength and therefore lower wave coherency, and probably more importantly due to the nonlinear response of significantly different surficial soil layers [27]. Figure 15a, in particular, illustrates that the strong long period ground motion previously discussed with respect to $\mathrm{CHHC}$ (i.e. Figure $7 \mathrm{~b}$ ) was observed at all four CBD stations and both Figure 15a and Figure $15 \mathrm{~b}$ illustrate that the seismic demands were above the 475 year return period design ground motion for Christchurch site class D as specified by the New Zealand loading standard, NZS1170.5 [9]. Furthermore, Figure 15b illustrates that for structures whose secant period at peak displacement is in the region of 1.5 or 3.5 seconds, the displacement demands imposed by the ground motion were in the order of two times the seismic design level.

\section{COMPARISON WITH GROUND MOTIONS OBSERVED IN THE 2010 DARFIELD EARTHQUAKE AND DESIGN SPECTRA}

The $M_{w} 6.3$ Christchurch earthquake was the second event in approximately six months to cause significant ground motion shaking in Christchurch, having been preceded by the 4 September 2010 Darfield earthquake [5]. In this section comparison is made between the ground motion intensities in these two events at various locations, and also with respect to seismic design spectra.

Figure 16 illustrates the geometric mean horizontal and vertical pseudo-acceleration response spectra of ground motions at various strong motion stations in Christchurch resulting from both the Christchurch and Darfield earthquakes, in addition to those that have been already presented for PRPC and HVSC in Figure 4. It can be immediately seen that for the majority of vibration periods of engineering interest the spectral amplitudes are larger for the Christchurch earthquake. The primary exception of the above statement is the spectral amplitudes at long vibration periods (i.e. $T>2 \mathrm{~s}$ ) due to both the longer duration of shaking and forward directivity effects in the Darfield earthquake [13]. Strong long-period spectral ordinates associated with these phenomena in the Darfield earthquake can be clearly seen at CCCC, RHSC and CACS stations. Figure 16a illustrates that at Christchurch Cathedral College (CCCC), which is located in the Christchurch CBD, spectral amplitudes in the Christchurch earthquake were approximately twice that of the Darfield earthquake for vibration periods less than $T=1.5 \mathrm{~s}$. It can also be seen that at CCCC station, spectral amplitudes resulting from the Darfield earthquake were notably below the design spectra for $T<2 \mathrm{~s}$. Figure 16c-Figure 16d also illustrate that spectral amplitudes from the Darfield earthquake were below the design spectra at short periods throughout the majority of Christchurch, with exceptions being Heathcote Valley (HVSC), Lyttelton Port (LPCC), and several western suburbs (i.e. TPLC, ROLC, LINC) not shown here [13].

Another notable feature illustrated in Figure 16 is the similarity of the response spectral shapes at a given site from these two events. In such an examination it is important to note the markedly different source locations of these two events, with the Christchurch earthquake occurring to the south-east, and the Darfield earthquake approximately $30 \mathrm{~km}$ west of, central Christchurch. Hence, the source and path effects of the ground motion at a single site are expected to be significantly different in both events. For example, Figure 16b and Figure 16c illustrate the similarity of response spectral shapes, for vibration periods less than $T=2 \mathrm{~s}$, of both horizontal and vertical ground motion components at Riccarton (RHSC) and Canterbury Aero Club (CACS). At vibration periods larger than $T=2 \mathrm{~s}$, the aforementioned source effects from the Darfield earthquake become significant (as well as 3D basin structure) and the response spectral shapes at a given site from these two events deviate. These observations clearly point to the importance of local site effects on surface ground motions, particularly at high to moderate vibration frequencies, and hence the benefits that can be obtained via site-specific response analysis as opposed to simple soil classification (recall that most of the sites in the Christchurch basin are assigned as site class D [9]). It should also be noted that the RHSC and CCCC sites discussed above, while experiencing significant ground motions, are founded on soils which did not exhibit liquefaction (which obviously causes a notable change in the stiffness and strength of the affected soils and hence modifies the near-surface site response). 
(a)

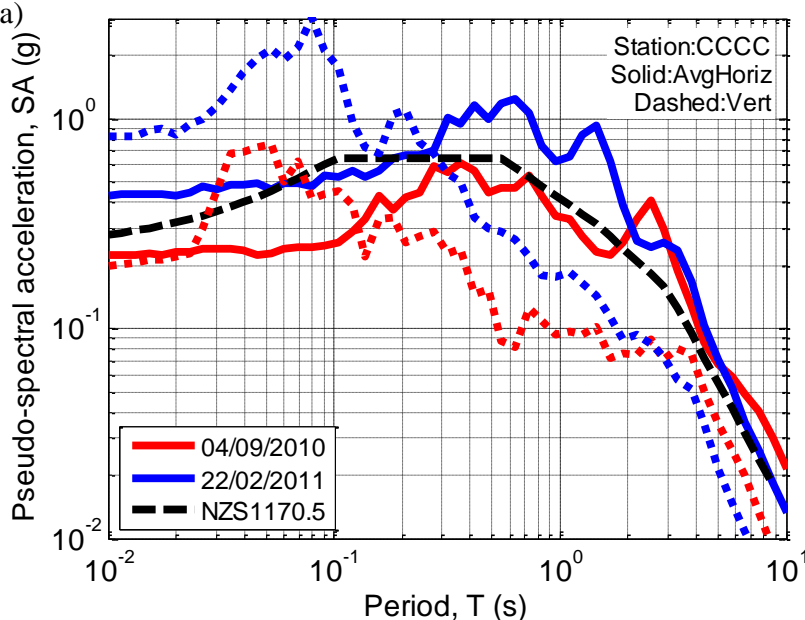

(c)

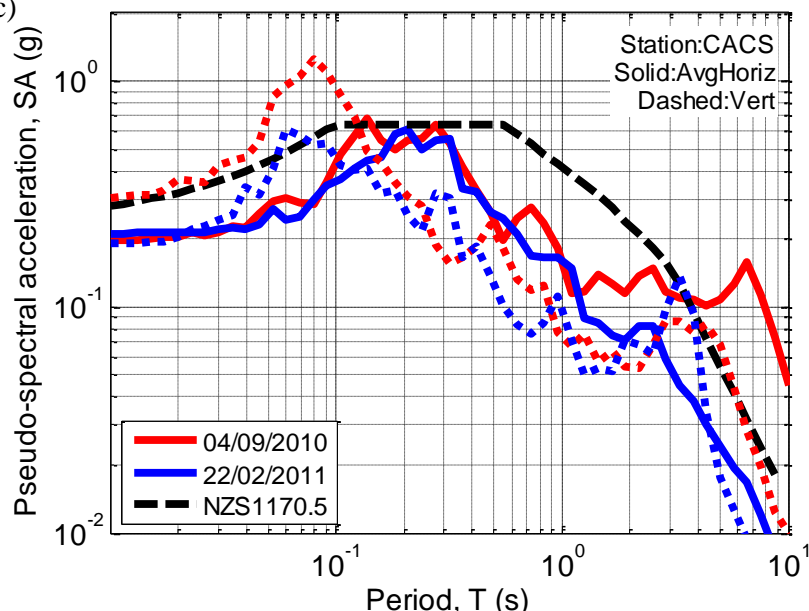

(b)

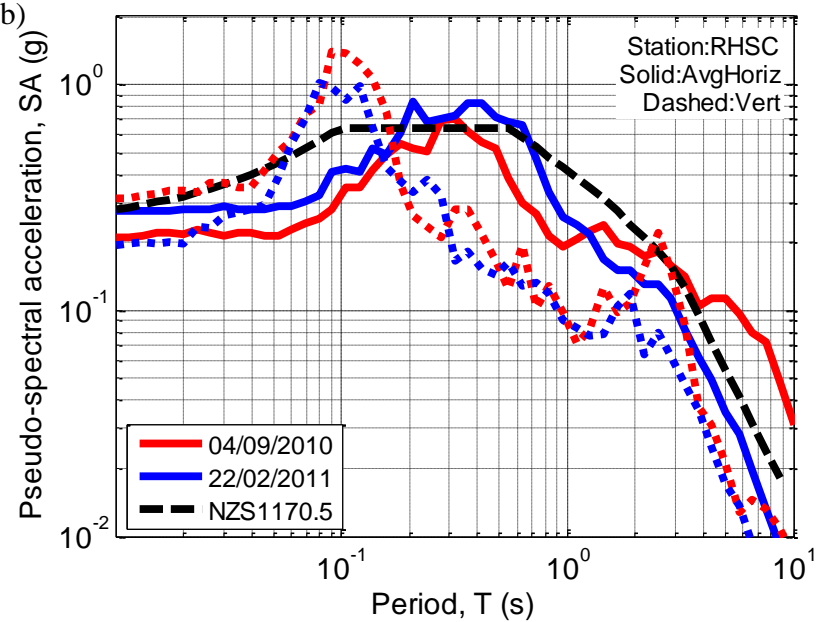

(d)

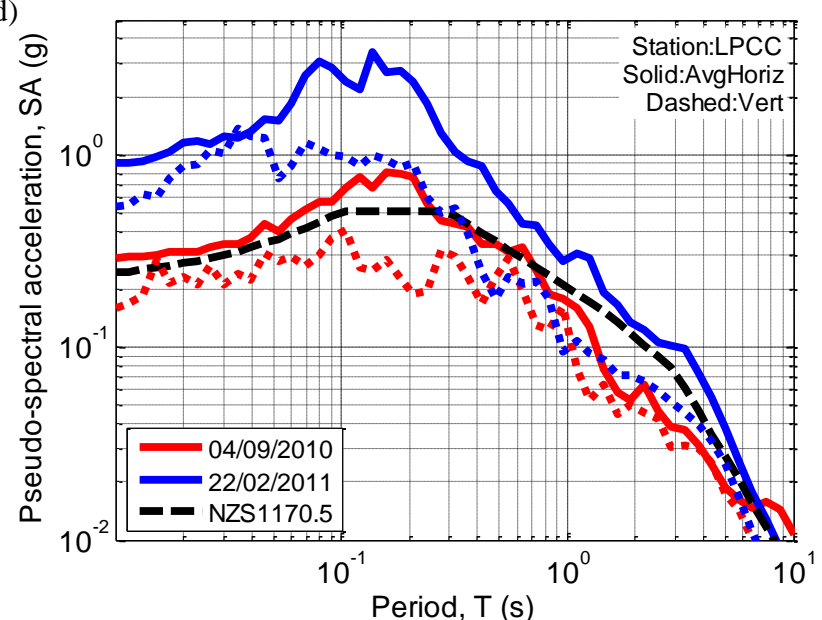

Figure 16: Comparison of geometric mean horizontal and vertical pseudo-acceleration response spectra observed in the 22/02/2010 Christchurch and 04/09/2010 Darfield earthquakes at various strong motion stations.

\section{CONCLUSIONS}

The 22 February $2011 \quad M_{w} 6.3$ Christchurch earthquake imposed severe ground motion intensities, which were in excess of the current seismic design spectra and those experienced in the 4 September 2010 Darfield earthquake, over the majority of the Christchurch region.

The dense set of near-source ground motions enable a detailed examination of salient features of the earthquake source, path and local site characteristics. It was seen that forward directivity due to the rupture propagation was evident at Pages Road (PRPC), however, such effects were not predominant over the region due to the inferred misalignment between the rupture font and slip vector. The large velocity contrast between the Christchurch sedimentary basin and underlying rock likely lead to a waveguide effect in which seismic waves were 'trapped' and propagated across the basin, principally resulting in an increase in long period response spectral amplitudes and ground motion durations. The severity of the ground motion intensity in the near-source region resulted in significant nonlinear soil behaviour and severe and widespread liquefaction which were evident in recorded acceleration time histories. The ratio between vertical and horizontal ground motion amplitude is strongly dependent on source-to-site distance, and weakly dependent on source magnitude or faulting style. It was seen that the vertical-to-horizontal response spectral ratios were similar for the Darfield and Christchurch earthquakes and hence the large vertical ground motions observed were simply a result of the significant number of near-source recordings rather than any eventspecific features.
On average, the observed ground motion amplitudes were seen to be consistent with empirical predictions for high frequencies, and the under-prediction for long periods is a likely result of the pronounced basin-generated surface waves, forward directivity and significant nonlinear soil behaviour observed. Discerning the relative contribution of each of these effects at various locations is the subject of ongoing work using more sophisticated methods of analysis.

The Christchurch earthquake produced ground motions in the majority of the eastern and central Christchurch region which had pseudo-acceleration response spectral amplitudes that were generally above the 475-year routine seismic design spectra, and also larger than those of the 4 September 2010 Darfield earthquake. At a single strong motion station, the similarity of response-spectral shapes of the ground motion observed from the Christchurch and Darfield earthquakes, for which source and path effects were largely different, also illustrated the significance of site-specific response for short and moderate vibration frequencies and hence that clearly more detailed subsurface investigations and modelling are needed to adequately infer the performance of soil and overlying structures in future earthquakes than simply using alphabet-based site classifications.

\section{ACKNOWLEDGEMENTS}

Dr. Weng Yuen Kam provided constructive comments on a draft of the manuscript, and discussions with Dr. John Beavan and Dr. John Berrill are greatly appreciated. 


\section{REFERENCES}

[1] New Zealand Police. (2011) "Christchurch earthquake: List of deceased".

[2] DeMets, C., Gordon, R.G., Argus, D.F. and Stein, S. (1994) "Effect of recent revisions to the geomagnetic time scale on estimates of current plate motion". Geophysical Research Letters; 21 2191-2194.

[3] Sutherland, R., Berryman, K. and Norris, R. (2006) "Quaternary slip rate and geomorphology of the Alpine fault: Implications for kinematics and seismic hazard in southwest New Zealand". Geological Society of America Bulletin; 118 464-474.

[4] Stirling, M.W., Gerstenberger, M., Litchfield, N., McVerry, G.H., Smith, W.D., Pettinga, J.R. and Barnes, P. (2007) "Updated probabilistic seismic hazard assessment for the Canterbury region". 58.

[5] NZSEE. (2010) "Special Issue: Preliminary observations of the 2010 Darfield (Canterbury) Earthquakes". Bulletin of the New Zealand Society for Earthquake Engineering; 43(4): 215-439.

[6] Beavan, J., Fielding, E.J., Motagh, M., Samsonov, S. and Donnelly, B.S. (2011) "Fault location and slip distribution of 22 February $2011 \mathrm{Mw} 6.3$ Christchurch, New Zealand, earthquake for geodetic data". Seismological Research Letters, Focused Issue on the 2011 Christchurch New Zealand Earthquake.

[7] Somerville, P.G., Ikikura, K., Graves, R.W., Sawada, S., Wald, D., Abrahamson, N.A., Iwasaki, Y., Kagawa, T., Smith, N. and Kowada, A. (1999) "Characterizing crustal earthquake slip models for the prediction of strong ground motion". Seismological Research Letters; 70(1): 59-80.

[8] Brown, L.J. and Weeber, J.H. (1992) "Geology of the Christchurch urban area", Geological and Nuclear Sciences 110

[9] NZS 1170.5. (2004) "Structural design actions, Part 5: Earthquake actions - New Zealand". Standards New Zealand: Wellington, New Zealand, 82.

[10] Bradley, B.A. (2010) "NZ-specific pseudo-spectral acceleration ground motion prediction equations based on foreign models" Report No.2010-03, Department of Civil and Natural Resources Engineering, University of Canterbury: Christchurch, New Zealand. 324.

[11] Aoi, S., Kunugi, T. and Fujiwara, H. (2008) "Trampoline Effect in Extreme Ground Motion". Science; 322(5902): 727-730.

[12] Yamada, M., Mori, J. and Heaton, T. (2009) "The Slapdown Phase in High-acceleration Records of Large Earthquakes". Seismological Research Letters; 80(4): 559-564.

[13] Bradley, B.A. (2012) "A critical analysis of strong ground motions observed in the 4 September 2010 Darfield earthquake". Soil Dynamics and Earthquake Engineering; (submitted).

[14] Aagaard, B.T., Hall, J.F. and Heaton, T.H. (2004) "Effects of Fault Dip and Slip Rake Angles on NearSource Ground Motions: Why Rupture Directivity Was Minimal in the 1999 Chi-Chi, Taiwan, Earthquake". Bulletin of the Seismological Society of America; 94(1): 155-170.

[15] Shahi, S.K. and Baker, J.W. (2011) "An Empirically Calibrated Framework for Including the Effects of Near-
Fault Directivity in Probabilistic Seismic Hazard Analysis". Bulletin of the Seismological Society of America; 101(2): 742-755.

[16] Hicks, S.R. (1989) "Structure of the Canterbury Plains, New Zealand from gravity modelling", Geophysics Division, Department of Science and Industrial Research: Wellington.

[17] Choi, Y., Stewart, J.P. and Graves, R.W. (2005) "Empirical Model for Basin Effects Accounts for Basin Depth and Source Location". Bulletin of the Seismological Society of America; 95(4): 1412-1427.

[18] Chiou, B.S.J. and Youngs, R.R. (2008) "An NGA Model for the average horizontal component of peak ground motion and response spectra". Earthquake Spectra; 24(1): 173-215.

[19] Cubrinovski, M., Green, R.A., Allen, J., Ashford, S.A., Bowman, E., Bradley, B.A., Cox, B., Hutchinson, T.C., Kavazanjian, E., Orense, R.P., Pender, M., Quigley, M. and Wotherspoon, L. (2010) "Geotechnical reconnaissance of the 2010 Darfield (Canterbury) earthquake". Bulletin of the New Zealand Society for Earthquake Engineering; 43(4): 243-320.

[20] Silva, W.J. (1997) "Characteristics of vertical strong ground motions for applications to engineering design, FHWA/NCEER Workshop on the National Representation of Seismic Ground Motion for New and Existing Highway Facilities, Burlingame, CA, Proceedings" Earthquake Spectra, National Center for Earthquake Engineering Research: Buffalo, New York.

[21] Bozorgnia, Y. and Campbell, K.W. (2004) "The verticalto-horizontal response spectral ratio and tentative procedures for developing simplified $\mathrm{V} / \mathrm{H}$ and vertical design spectra". Journal of Earthquake Engineering; 8(2): 175-207.

[22] Chiou, B., Youngs, R., Abrahamson, N. and Addo, K. (2010) "Ground-Motion Attenuation Model for Small-ToModerate Shallow Crustal Earthquakes in California and Its Implications on Regionalization of Ground-Motion Prediction Models". Earthquake Spectra; 26(4): 907-926.

[23] Pinheiro, J., Bates, D.M., DebRoy, S., Sarkar, D. and the R Core team. (2008) "nlme: linear and nonlinear mixed effects models".

[24] Abrahamson, N.A. and Youngs, R.R. (1992) "A stable algorithm for regression analyses using the random effects model". Bulletin of the Seismological Society of America; 82(1): 505-510.

[25] Bradley, B.A. (2011) "Correlation of significant duration with amplitude and cumulative intensity measures and its use in ground motion selection". Journal of Earthquake Engineering; (in press).

[26] Bommer, J.J., Stafford, P.J. and Alarcon, J.E. (2009) "Empirical Equations for the Prediction of the Significant, Bracketed, and Uniform Duration of Earthquake Ground Motion". Bulletin of the Seismological Society of America; 99(6): 3217-3233.

[27] Cubrinovski, M., Bray, J.D., Taylor, M.L., Giorgini, S., Bradley, B.A., Wotherspoon, L. and Zupan, J. (2011) "Soil liquefaction effects in the Central Business District during the February 2011 Christchurch earthquake". Seismological Research Letters, Focused Issue on the 2011 Christchurch New Zealand Earthquake. 